\title{
Factors associated with international students' motivations to study at West Virginia University
}

\author{
Abimbola Akintounde \\ West Virginia University
}

Follow this and additional works at: https://researchrepository.wvu.edu/etd

\section{Recommended Citation}

Akintounde, Abimbola, "Factors associated with international students' motivations to study at West Virginia University" (2009). Graduate Theses, Dissertations, and Problem Reports. 2791.

https://researchrepository.wvu.edu/etd/2791

This Thesis is protected by copyright and/or related rights. It has been brought to you by the The Research Repository @ WVU with permission from the rights-holder(s). You are free to use this Thesis in any way that is permitted by the copyright and related rights legislation that applies to your use. For other uses you must obtain permission from the rights-holder(s) directly, unless additional rights are indicated by a Creative Commons license in the record and/ or on the work itself. This Thesis has been accepted for inclusion in WVU Graduate Theses, Dissertations, and Problem Reports collection by an authorized administrator of The Research Repository @ WVU. For more information, please contact researchrepository@mail.wvu.edu. 
Factors Associated with International Students' Motivations to Study at West Virginia University

Abimbola Akintounde

Thesis submitted to the Davis College of Agriculture, Forestry, and Consumer Sciences at West Virginia University in partial fulfillment of the requirements for the degree of

Master of Science

in

Agricultural and Extension Education

Deborah A. Boone, Ph.D., Chair

Harry N. Boone, Jr., Ph.D.

Douglas D. LaVergne, Ph.D.

Division of Resource Management

Morgantown, West Virginia

2009

Keywords: Motivation, International Students 


\begin{abstract}
ABSTACT
Factors Associated with International Students' Motivations to Study at West Virginia University

Abimbola Akintounde

Increasing international student enrollments requires an understanding of international students' motivations for studying abroad. This study sought to identify the factors associated with international students' motivation to study in the United States and particularly at West Virginia University. An internet survey was sent via email to all 1183 international students enrolled at WVU in spring of 2009. A 29.4\% response rate (344 students) was achieved. Based on an analysis of responses received, respondents' top motivations for studying at WVU included the United States' reputation for high quality teaching, respect for United States degrees abroad, the global perspective the United States offers all careers, better teaching aids and the preference of employers in respondents' home countries for United States earned degrees. The top factors influencing the respondents' choice of WVU were the availability of financial aid at WVU, higher demand to international degrees by employers, positive recommendations from students abroad, and the prevalence of advanced research techniques at WVU.
\end{abstract}




\section{DEDICATION}

This handiwork is dedicated to my Lord and Source. You are my help and

fortress. And to my love and sweetest - Leslie, you are cherished beyond words. I'll love you till the end. 


\section{ACKNOWLEDGEMENT}

I am sincerely grateful to all those who have helped make my graduate studies at West Virginia University a reality. I would like to thank Dr. Jerry Fletcher for his kind gestures and assistance rendered during my graduate admission. My appreciation also goes to Dr. Jonathan Cumming, the Assistant Vice President for Graduate Education Office of Graduate Education and Life, for the tuition waiver granted to support my graduate degree.

I would like to especially thank my advisor, Dr. Deborah Boone. Her support, guidance and corrections made this research work a realizable dream. Thank you for all the efforts you put into supervising this study. I wish to express my gratitude to Dr. Harry Boone for imparting an invaluable deal of hands-on experience in research methodologies and data analysis to me through those "late night" classes. I found them very helpful in every chapter of this thesis. Many thanks to Dr. LaVergne for every input and suggestions he provided to improve the quality of this study.

I will also like to take this opportunity to thank Mr. Kharivat Narayanan of the Office of International Students and Scholars and all my fellow WVU international students for participating in the survey. Your contributions and comments made this research a reality.

My acknowledgement will not be complete without acknowledging my appreciation to my sister and family, who provided shelter and moral support throughout my graduate program. I love you and I appreciate every one of you. Thanks a lot. 


\section{TABLE OF CONTENTS}

Page

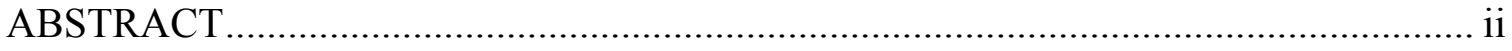

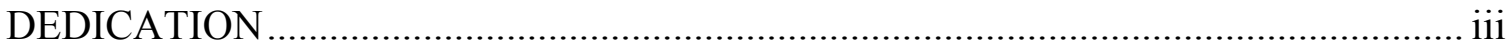

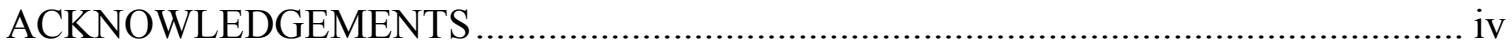

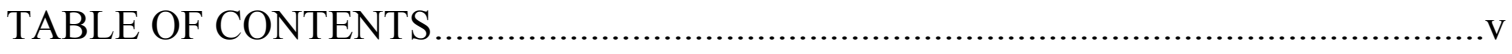

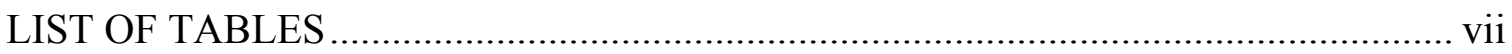

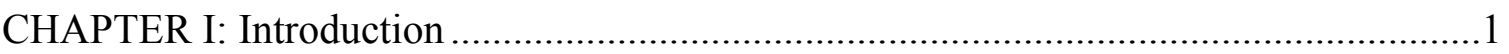

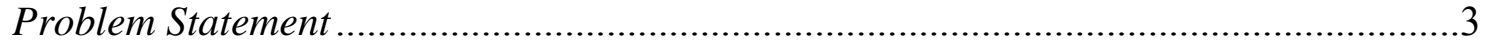

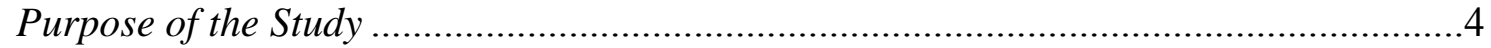

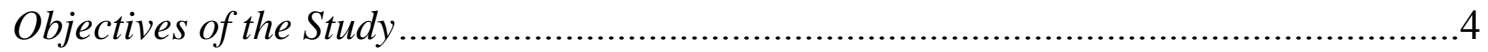

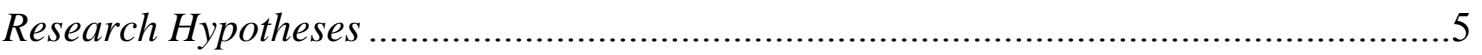

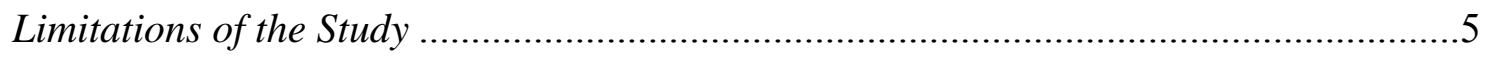

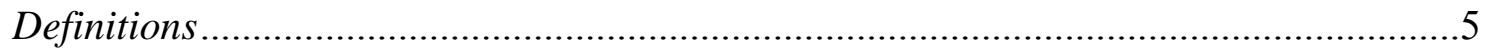

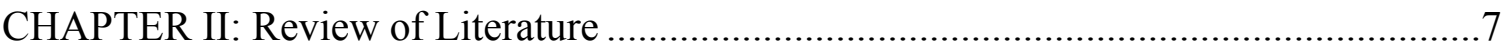

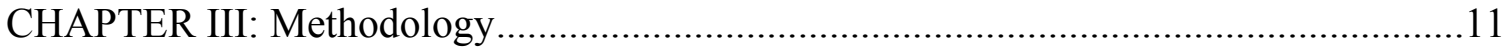

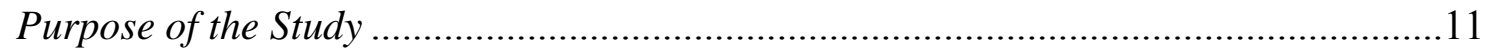

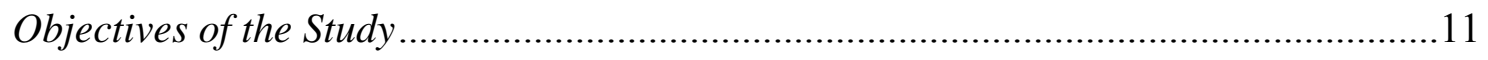

Research Hypotheses ..............................................................................................11

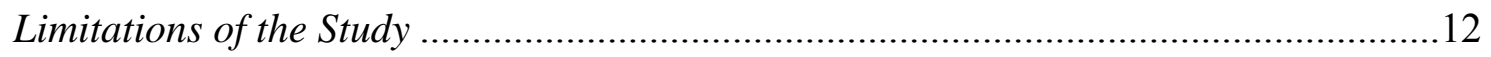

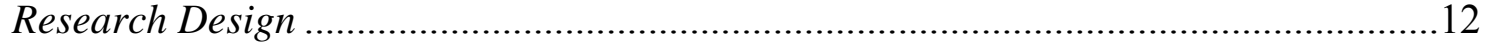

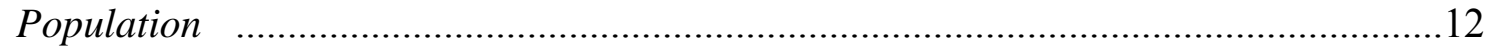

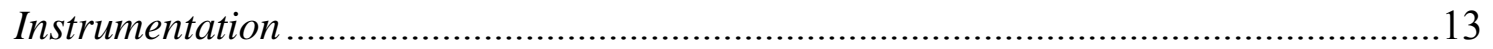

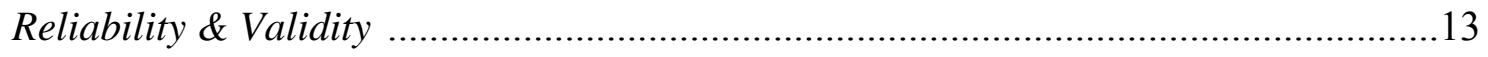

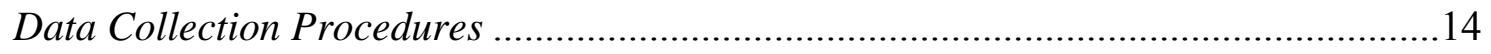

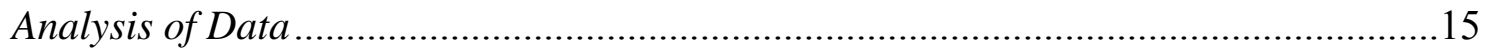

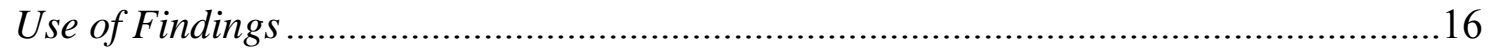

CHAPTER IV: Findings .......................................................................................18

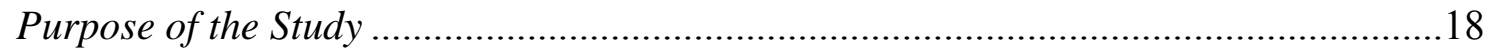

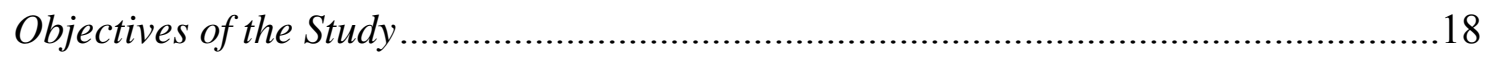

Research Hypotheses ........................................................................................18

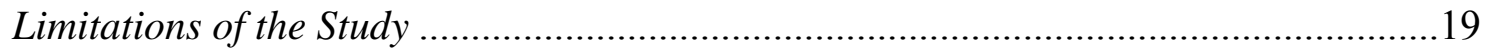


Findings 19

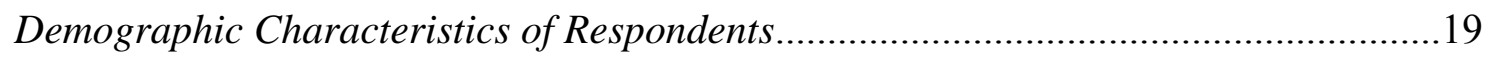

Motivations for Studying at West Virginia University ................................................29

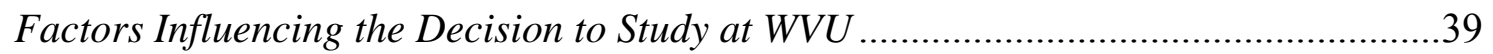

Constraints Affecting International Students' Decisions to Study in the United

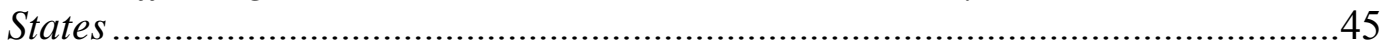

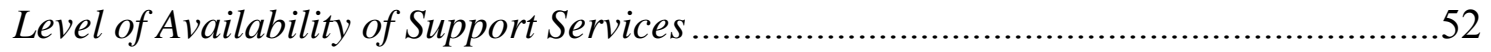

Relationship Between Support Services and Motivation for Studying at WVU...............55

CHAPTER V: Summary, Conclusions, and Recommendations ......................................57

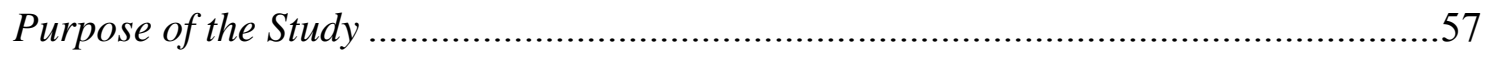

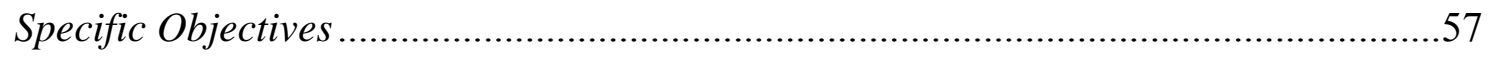

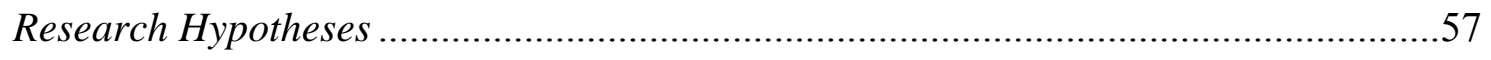

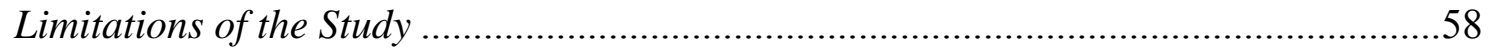

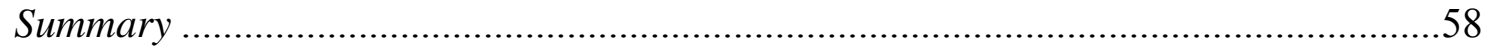

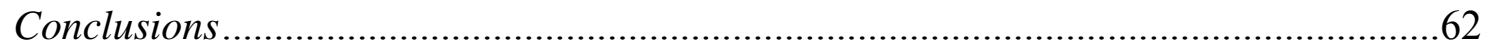

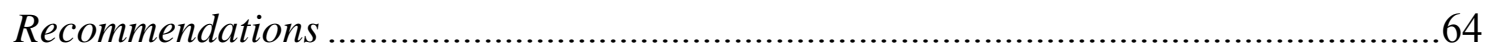

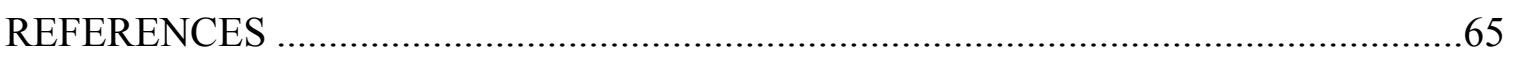

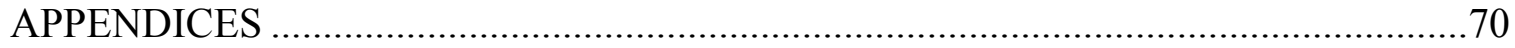

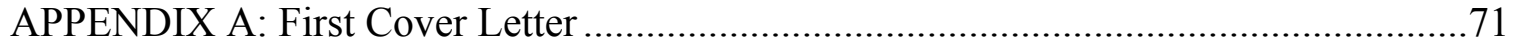

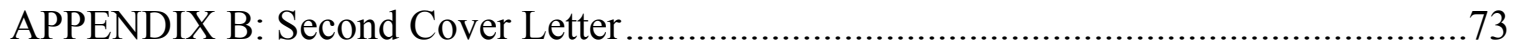

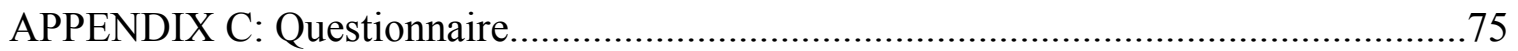

APPENDIX D: Full list of Respondents' Countries of Origin ...........................................84

APPENDIX E: Other Factors that Influenced International Students' Decisions ..............89

APPENDIX F: Other Constraints Listed by International Students ..................................92

APPENDIX G: Other Support Services Listed by International Students .........................94

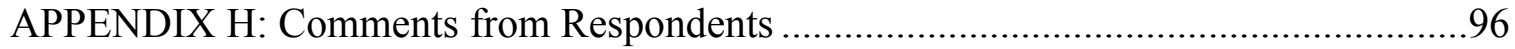

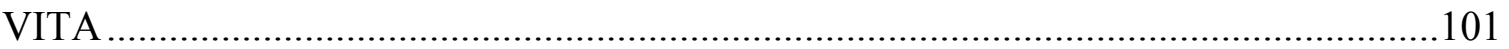




\section{LIST OF TABLES}

Table Title Page

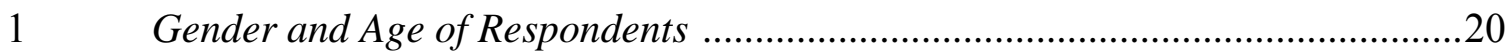

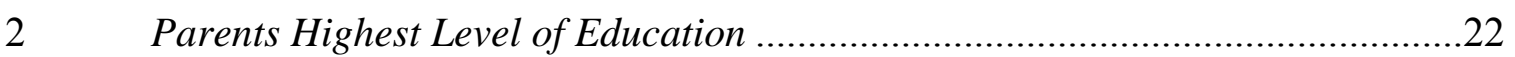

3 Respondents' International Travel and International Study Exposure ..............23

$4 \quad$ Duration of study in the United States and at WVU ......................................23

$5 \quad$ Highest Education Level Attained in Home Country \& Academic Status at

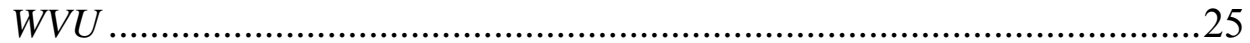

6 Distribution of Respondents by Colleges across WVU .....................................26

$7 \quad$ Respondents benefiting from WVU Graduate Assistantships ............................26

8 Distribution of Respondents by Countries of Origin .......................................27

9 Sources of Information about Studying in the United States .............................28

10 Motivations for Studying at West Virginia University .......................................36

$11 \quad$ Factors Influencing the Decision to Study at WVU ...........................................43

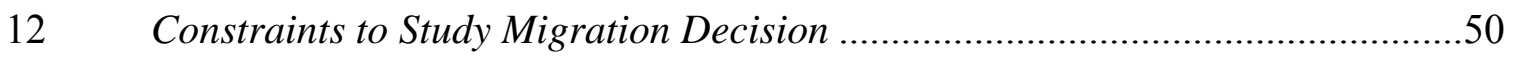

13 Level of Availability of Support Services in Home Countries..............................54

14 Relationship between Level of Availability of Support Service and

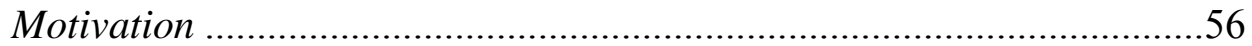

$15 \quad$ Full List of Respondents' Countries of Origin ..................................................83 


\section{CHAPTER I}

Introduction

Globally, the number of students studying outside their home country has risen and will continue to rise (Hatakenaka, 2004). The United States is regarded as the premier destination for diverse international students and stands as the world leader in international student enrollment, hosting close to a quarter of all international students worldwide (UNESCO, 2006). In the 2007-2008 academic year, the National Association of State Facilities Administrators (NASFA) reported that international students and their dependents contributed approximately $\$ 15.54$ billion to the U.S. economy. At West Virginia alone, it was estimated that foreign students contributed about $\$ 50.7$ million to the state's economy during this time period (NASFA, 2008).

Since a vibrant international student population translates to a strong economic advantage and a multicultural heritage for any host institution. Many universities and colleges are intensifying efforts towards manipulating factors that could increase international students' enrollment. As stated by the American Association of State Colleges and Universities (AASCU), "U.S. colleges and universities have raised their visibility abroad and they are devoting more resources and improving infrastructures to attract and retain the interest of international students in their campuses" (Verbik, 2007, p.3). However, international students have a plethora of choice among universities both in the United States and other foreign countries. Hence, host universities in the United States must strive to identify international students' motivations for study migration and appropriately distinguish themselves competitive in order to secure and maintain an increased enrollment of students from across the globe. 
West Virginia University (WVU) offers international and domestic students an array of degrees ranging from agriculture, forestry, and consumer science, to business and economics, the creative arts, education, engineering and mineral resources, humanities, journalism, law, medicine, dentistry, nursing, pharmacy, the natural and social sciences, physical education, and social work (WVU, 2008). These multidisciplinary opportunities attract students from several countries, thus, creating diversity, which offers an inspiring study climate for a variety of foreign students. However, incessant reports showing declines in international student enrollments across the United States is alarming.

According to Slagle (2006), the number of foreign students enrolled in U.S. colleges and universities has been falling since the fall of 2002, when the Institute of International Education (IIE) reported more than 586,000 students were enrolled. It was noted in 2004 that foreign student enrollment had decreased to 565,000 students, a decline of nearly four percent (IIE, 2005). The Council of Graduate Schools (CGS) in the United States also reported a substantial drop in international graduate student applications nationwide (American Association of University Professors, 2004). After a study affirming a reduction in Saudi students' population in the United States, Grant (2003) concluded that the occurrence of deterioration in foreign student enrollments cannot be ruled out. It has also been reported that the number of international students studying at West Virginia University declined over time. Slagle (2006) reported there was a record high of 1,412 international students at West Virginia University in 2003, but that this number subsequently slid for two years, such that in 2006, there were only 1,264 international students, enrolled in the institution. A database maintained by 
WVU Admissions and Records Office revealed that1,183 international students were enrolled at West Virginia University during the spring semester of 2009.

\section{Problem Statement}

Today's educational policy makers, market analysts and advocates have become concerned about declines in the United States' competitiveness in the international student market. Shenoy (2002) reported that the U.S. share of internationally-mobile students pursuing higher education at foreign institutions in 1982 was $40 \%$. However, according to the Organization for Economic Co-operation and Development (OECD) declared that this percentage had declined to $32 \%$ in the year 1998 (Verbik, 2007).

Although, the United States is still reported as the leading destination for international students, the nation is recently combating rising competition from other countries for foreign students (IIE, 2005). According to the American Council on Education (2006), international student enrollment in the United States peaked in 200203 , and then declined in the following two years, by 2.4 percent and 1.3 percent, falling from 586,323 students in $2002-03$ to 565,039 in $2004-05$. The Institute of International Education reported that a drop in undergraduate enrollment of international students accounted for much of this decline (IIE, 2005).

Transitions in the international student market offer foreign students more alternatives for international education, and as a result, students who initially would have attended United States institutions of higher education are looking elsewhere. A number of factors continually contribute to this decline, thus making the choice of higher education in the United States unwelcoming to some international students. For instance, a 2003 IIE report itemized visa approval delays, political concerns, financial constraints, 
and students' choices of more attractive opportunities elsewhere as obstacles to Saudi Arabians choice of studying in the United States (Grant, 2003). While several studies have been conducted on international migration and study abroad trends, it is reported that the study of marketing international education is fragmented, with little research into why students select a study destination and how they choose and evaluate their host institutions (Knight \& De Wit, 1995; Lawley, 1993). It is against this background that the study of factors influencing international students' choice to undertake higher education in United States has become imperative.

\section{Purpose of the Study}

This study was designed to determine factors that influence international students' decisions to enroll at West Virginia University. An overall assessment of the motivating factors and impeding constraints to foreign student's choice of United States higher institutions is crucial to restructuring international student recruitments by providing insights to the mitigating forces hampering foreign student enrollment in United States universities.

\section{Objectives of the Study}

This research was supported by the following questions:

1. What are the perceived constraints to the migration choice of international students?

2. What factors motivate international students to migrate for higher education?

3. What is the level of availability of study abroad support services in their home countries?

4. What are the demographic characteristics of these international students? 


\section{Research Hypotheses}

The research posed the following hypotheses for assessing international students' motivations to study in the United States:

$\mathrm{H}_{0}$ : There is no association between the level of availability of support services in home countries and the motivation of international students for studying at West Virginia University.

$\mathrm{H}_{1}$ : There is a significant association between the level of availability of support services in home countries and the motivation of international students for studying in the West Virginia University.

\section{Limitations of the Study}

The scope of this research is limited to only international students at West Virginia University. Although the generalizability of these findings may extend to universities with similar sizes of international students, caution must be exercised in generalizing these results with different populations, demographics, and geographical locations. The results of this study are not generalizable to all international students in the United States.

\section{Definition of Terms}

International Student: Shenoy (2002) defined an international student as a student who (1) is a citizen or permanent resident of a country other than that in which he or she intends to study; (2) has a legal residence outside the country that he or she intends to study in; and (3) proposes to be in the host country solely for educational purposes. 
Motivation: Motivation is the set of factors that influences an individual's decision to engage in or refrain from a particular behavior (Kiviniemi \& Bevins, 2007). 


\section{CHAPTER II}

\section{Review of Literature}

The international student market is rapidly changing worldwide. Verbik (2007) declared "international student mobility has become an increasingly important part of the global higher education landscape" (p.3). According to the IIE's 2008 Open Doors Report, "international students in the United States Higher Institutions contribute over $\$ 15.5$ billion to the United States economy through their expenditures on tuition and living expenses." (para.12) In the United States, higher education is one of the largest service sector exports because international students generate revenue for the national economy and their host states through their tuition and living expenditures, such as room and board, books and supplies, transportation, health insurance, and support for accompanying family members (IIE, 2008).

An increasing number of opportunities for pursuing higher education within home countries and several other countries abroad are contributing to rising competition in the foreign student market (Verbik, 2007). For decades, international students have predominantly migrated to the United States, the United Kingdom and Australia in pursuing their higher education. With approximately $45 \%$ of the total amount of all foreign students, these three countries rank first amongst the most popular destination countries for overseas studies, with the United States as the undisputed frontrunner, having approximately 565,000 foreign enrollments in 2006 (Verbik, 2007). In order to attract the growing number of international students seeking higher education, various higher institutions and countries are accelerating efforts to differentiate themselves from their competitors. 
In the United States, higher education institutions are organizing and implementing recruitment strategies to increase overseas student enrollment. Soo \& Elliott (2008) suggested that attracting overseas students should remain an important objective for higher education institutions today, because of economic benefits, as well as, the diversity of experience that they bring to undergraduate and postgraduate programs. However, designing recruitment programs, which will attract and retain the interest of international students for enrollment, calls for a closer assessment of overall factors that influence their study abroad decision making. This requires an examination of demographic variables and structural forces that influence the motivation of overseas students in selecting study destinations. Motivational factors influencing international study migration must be identified, in order to be effectively utilized in escalating foreign student enrollment in United States higher education institutions.

A survey of international students' mobility revealed that students with preuniversity international experience were more likely to migrate to study abroad. It was also disclosed that students from low-income families explore travel abroad opportunities less than students from high income families (Schnitzer \& Zempel Gino, 2002). Lawley (1993) itemized four underlying factors, namely study program characteristics, host and home country characteristics, characteristics of the administrative processes involved, and cost characteristics, which could usefully disaggregate factors determining international students choice of foreign universities for higher education. The preference of international qualifications over locally acquired degrees by employers in a student's home country was also regarded an important variable influencing their choice of destination country (Lawley, 1993). Variables, such 
as the economic and political situations in their home countries and the imagery of the host country reported by friends and families abroad can influence students' choice of destination countries. Also variables contributing to administrative processes, which include the ease of gaining entry to universities, ease of obtaining a student visa, ease of gaining exemptions, availability of information about a destination and permission to legally work part-time, are instrumental to the decision of many students choosing the United States (Rao, 1979; Bureau of Industry Economics, 1989; Hill, Romm \& Patterson, 1992). Also, study migration cost, which encompasses variables such as comparative financial and psychological costs, the distance from home, climate and levels of racial discrimination were affirmed to impact foreign students' choice of destinations abroad (Chandler 1989; IDP 1994)

Findings from a nationwide Student Satisfaction Inventory conducted among international students in the United States itemized academic reputation, the cost of attending college and the availability of financial aid (regardless of the type of institution students attend) as important influences on the travel decisions of foreign students. The utmost concern of the international students was the cost of financing tuition and living expenses for their foreign education (Noel-Levitz, 2007).

Shenoy (2002) opined that the global market for international higher education may be explained in terms of an interaction between supply-side factors and demand-side factors. Demand side forces are those host country features attracting international students to immigrate to United States institutions. These include, economic, political and security situations and academic facilities existing in their destination institutions. The supply side factors included inadequate teaching and research facilities, limited openings 
at the university level, discrimination against domestic degrees and a bias for foreign qualifications, as well as, an array of political and economic factors at home that influences students to depart their home countries for foreign education. Mazzarol \& Geoffrey (2002) also investigated certain demand-side variables driving overseas students to migrate abroad in pursuit of higher education. Certain incentives, such as the availability of scholarships, better infrastructures and teaching facilities, political ties and cultural and linguistic similarities with the host country, and also, the hope that a foreign educational credential will help in obtaining a better job on their return to their home country pull students towards host countries.

A survey of international students on factors influencing their study migration decisions unveils forces that are instrumental in international students' choice to studying abroad. While this research is of interest to policy making in international higher education in both home and host countries, it is hoped that factors identified are utilized to guide policies and decision making on international student enrollment at West Virginia University and other universities and colleges across the United States. 


\section{CHAPTER III}

\section{Methodology}

\section{Purpose of the Study}

The purpose of this study was to determine factors influencing international students' decisions to enroll at West Virginia University. This research provides insight on the motivations and drivers for increasing foreign student enrollment in host institutions, as well as, challenges and barriers to their enrollment. This information is considered relevant to improving outreach and marketing strategies utilized by United States' host institutions for increasing international student enrollment. Objectives of the Study

This research was supported by the following questions:

1. What are the perceived constraints to the migration choice of international students?

2. What factors motivate international students to migrate for higher education?

3. What is the level of availability of study abroad support services in their home countries?

4. What are the demographic characteristics of these international students?

\section{Research Hypotheses}

The research posed the following hypotheses for assessing international students' motivation to study in the United States:

$\mathrm{H}_{0}$ : There is no association between the level of availability of support services in home countries and the motivation of international students for studying at West Virginia University. 
$\mathrm{H}_{1}$ : There is a significant association between the level of availability of support services in home countries and the motivation of international students for studying in the West Virginia University.

\section{Limitations of the Study}

The scope of this research is limited to only international students from West Virginia University. Although the generalizability of these findings may extend to universities with similar sizes of international students, caution must be exercised in generalizing these results with different populations, demographics, and geographical locations. The results of this study are not generalizable to all international students in the United States.

\section{Research Design}

A descriptive research design was selected to obtain data from international students to determine the factors influencing their choice of a higher education at West Virginia University. According to Ary, Jacobs, Razavieh, and Sorenson (2006), descriptive research acquires information from a population in order to summarize their characteristics and measure attitudes and opinions toward some issue. Information was obtained by a census of international students at West Virginia University, using an internet-based survey. Data were analyzed using descriptive statistics such as percentages, means, and standard deviations to report observations.

\section{Population}

The target population consisted of international students enrolled at West Virginia University in the spring semester of 2009. Frame error was avoided by using an official list of international students, maintained by WVU's Office of Admissions and Records. 
The list was reviewed for duplicate names and email addresses to avoid selection error. A census was then conducted on the total 1183 international students enrolled in spring, 2009. However, 11 electronic emails bounced as undeliverable due to invalid e-mail addresses, thereby limiting the accessible population to 1172 international students with functional WVU email addresses.

\section{Instrumentation}

The instrument used for this study was an Internet survey developed by the researcher using West Virginia University Simple Forms. The questionnaire was divided into four sections. The first section enlisted 21 attitudinal statements about motivations for studying at West Virginia University, which were rated on a six-point Likert scale, ranging from Strongly Agree $=6$, Agree $=5$, Agree Slightly $=4$, Disagree Slightly=3, Disagree $=2$ to Strongly Disagree $=1$. The second section consisted of 11 items describing factors influencing their choice to study at WVU that were rated on a six-point Likert scale. The third section was composed of 16 perceived constraints to studying in the United States, which were ranked by respondents on a six-point Likert scale, while the fourth section listed eight support services, which were ranked according to the level of availability in respondents' home countries, ranging from not available at all, low availability, moderately available to high availability. The last section of the instrument included items describing the students' demographic characteristics.

\section{Reliability and Validity}

Measurement error was reduced by establishing the validity and reliability of the instrument used for collecting data. The instrument was presented to a panel of experts to establish its content and face validity. This panel consisted of agricultural and extension 
education faculty members, who had extensive research experience in educational research. The panel of experts concluded that the instrument had content and face validity.

The final data set obtained from respondents was used to determine the instrument's reliability. The items rated on the six-point Likert scale were tested for reliability by using the Spearman-Brown split-half coefficient. The equal-length Spearman-Brown statistic (Pearson $r=0.78$ ) was used to establish the instrument's reliability. The instrument was considered to have an exemplary reliability (Robinson, Shaver, \& Wrightsman, 1991).

Data Collection Procedures

A cover letter (see Appendices A \& B) and the link to the Internet survey questionnaire on WVU Simple Forms (see Appendix C), were sent electronically to each international student in the target population via their West Virginia University e-mail account. Following Dillman's (2000) tailored design method, the cover letter detailed the purpose of the research, and solicited student's participation, while also assuring the international students of the confidentiality of any information disclosed. On April 27, 2009, a cover letter introducing and explaining the purpose of the study, as well as, the Internet link to the questionnaire was e-mailed to all international students, through the Office of International Students. Participants were given an initial deadline date of two weeks (May 6, 2009) to complete and submit the survey instruments.

After the first electronic mailing of the link to the internet survey, a follow-up email was sent on May 1, 2009 to remind non respondents to complete the survey. On May 8, 2009, a second email, including a cover letter and the Internet questionnaire link 
was sent once again to all WVU international students. On May 10, 2009 a third email, comprising a cover letter and the Internet questionnaire link was sent to every international student from the researcher, giving another deadline of May 15, 2009 to allow late respondents to participate in the survey. On May 20, 2009 a final email was sent electronically to all international students to maximize their participation in the survey. Students were given a final deadline of May 22, 2009 to participate in the electronic survey before the online questionnaire was closed. In order to secure adequate responses to the survey, respondents were sent seven emails to invite participation in the online survey (Ary et al., 2006).

Non-response error was assessed by using chi-square test to compare early respondents to late respondents based on three variables, namely gender, current educational status at WVU, and highest level of education attained in home country, since "non respondents are known to be similar to late respondents" (Ary et al., 2006, p. 439). Based on these three demographic variables, no significant difference was found between early respondents and late respondents. Therefore, the findings of this study are representative of the target population and results could be generalized to the entire target population (Ary et al., 2006).

\section{Analysis of Data}

The anonymity of respondents and the disclosed information was ensured by excluding personal information, such as respondent's names from the questionnaires. Data received from respondents were entered into an Excel Spreadsheet, while openended responses and comments were documented in full text format and grouped together based on similarity in responses (see Appendices $\mathrm{E}-\mathrm{H}$ ). 
The Statistical Package for Social Sciences (SPSSX, Version 11) was used to analyze the collected data. The level of significance was set $a$ priori at $\leq 0.05$ for all statistical tests. Descriptive analyses were performed on the data and the appropriate methods of measuring central tendency and variability was analyzed for each data set. The responses to the items about International students' motivations to study at WVU were analyzed on an ordinal scale. Factors influencing their decision to migrate to the United States for a higher education were analyzed. Responses stated as constraints to WVU international students' decision to study in the United States were analyzed on an ordinal scale to identify the top constraints itemized by respondents.

Aggregate scores for motivations, influences, and constraints were calculated for each respondent by taking the mean of the Likert items on the motivations, influences and constraints sections of the questionnaire, respectively. The following system was used to interpret the mean scores: "strongly disagree" $=1.00-1.50$, "disagree" $=1.51$ 2.50 , "slightly disagree" $=2.51-3.50$, "agree slightly" $=3.51-4.50$, "agree" $=4.51-5.50$ and "strongly agree" $=5.51-6.00$. The research hypothesis of this study was analyzed by performing a Pearson's R correlation to test for associations between the levels of availability of support services in respondents' home countries and their motivations to study at WVU.

Use of findings

Based on the findings of this study, it was possible to estimate some relevant factors and impeding constraints to foreign students' choice of a higher education at United States institutions. It is envisioned that outcomes of this research will help guide policies formulated for international education and will be beneficial to West Virginia 
University's international student recruitment by providing insights to the mitigating forces hampering foreign student enrollment in United States universities, particularly West Virginia University. 


\section{CHAPTER IV}

\section{Findings}

\section{Purpose of the Study}

The purpose of this study was to determine factors influencing international students' decisions to enroll at West Virginia University. This research provides insight on the motivations and factors for increasing foreign student enrollment in host institutions, as well as, challenges and barriers to their enrollment. This information is considered relevant to improving outreach and marketing strategies utilized by United States' host institutions for increasing international student enrollment. Objectives of the Study

This research was supported by the following questions:

1. What are the perceived constraints to the migration choice of international students?

2. What factors motivate international students to migrate for higher education?

3. What is the level of availability of study abroad support services in their home countries?

4. What are the demographic characteristics of these international students?

\section{Research Hypotheses}

The research posed the following hypotheses for assessing international students' motivation to study in the United States:

$\mathrm{H}_{0}$ : There is no association between the level of availability of support services in home countries and the motivation of international students for studying at West Virginia University. 
$\mathrm{H}_{1}$ : There is a significant association between the level of availability of support services in home countries and the motivation of international students for studying in the West Virginia University.

\section{Limitations of the Study}

The scope of this research is limited only to international students from West Virginia University. Although the generalizability of these findings may extend to universities with similar sizes of international students, caution must be exercised in generalizing these results with different populations, demographics, and geographical locations. The results of this study are not generalizable to all international students in the United States.

\section{Findings}

The target population for this study was all international students enrolled at West Virginia University in the spring semester of 2009. The target population comprised a total of 1183 international students. Eleven surveys were returned as undeliverable due to invalid e-mail addresses, thereby reducing the accessible population to 1172 international students with functional WVU email addresses. Of the entire accessible population, 344 (29.4\%) of the Internet based surveys were returned by respondents. However, 19 of the 344 questionnaires submitted were incomplete and considered void with unusable data, reducing the utilizable responses to $325(27.7 \%)$.

\section{Demographic Characteristics of Respondents}

Respondents were asked to complete 16 multiple choice questions and three openended questions that concern each respondent's demographic characteristics. These included gender, age, highest level of education of parents, prior international travel 
exposure, current educational status and major at WVU, highest level of education at home country, length of duration studying in the United States and at West Virginia University, as well as, sources of information about studying in the United States.

One hundred and eighty-two (59.9\%) respondents were male and $122(40.1 \%)$ were female. Thirty-one (10.2\%) respondents were $18-21$ years of age, $83(27.2 \%)$ respondents were 22 and 25 years and $122(40 \%)$ respondents stated they were in the 2630 years category. Forty-five (14.8\%) respondents were between $31-35$ years of age, 16 (5.2\%) respondents reported they were between 36-40 years of age, and eight $(2.6 \%)$ respondents stated they were over 40 years old (see Table 1).

Table 1

Gender and Age of Respondents

N $\%$

Gender

Male

182

59.9

Female

122

40.1

Age

18-21 years

22-25 years

26-30 years

40.0

31-35 years

45

14.8

$36-40$ years

16

5.2

Over 40 years

8

2.6 
Participants in the study were asked to indicate their parents' highest level of education. Six (1.9\%) respondents stated their fathers had no formal schooling, $18(5.8 \%)$ students reported that their fathers only had elementary school, 16 (5.2\%) of the respondents indicated their father's highest education as vocational studies, $64(20.8 \%)$ respondents stated their father's highest level of education was high school, 112 (36.4\%) individuals reported their father's highest level of education was a Bachelors degree, 65 (21.1\%) respondents stated their fathers' held a Masters/graduate certificate, while 27 $(8.8 \%)$ of the respondents indicated a doctorate as their father's highest level of education. Fourteen (4.6\%) respondents stated their mothers had no formal schooling, 37 (12.1\%) students reported that their mothers only attended elementary school, $17(5.6 \%)$ of the respondents indicated their mother's highest level of education as vocational studies, 99 (32.4\%) of the respondents stated their mother's highest level of education was high school, 99 (32.4\%) individuals also reported their mother's highest degree was a Bachelors degree, $30(9.8 \%)$ respondents stated their mothers' highest education was a Masters/graduate certificate, and $10(3.3 \%)$ of the respondents indicated a Doctoral degree as their mother's highest level of education (see Table 2). 
Table 2

Parents Highest Level of Education

\begin{tabular}{lcccc}
\hline & \multicolumn{2}{c}{ Father } & \multicolumn{3}{c}{ Mother } \\
\cline { 2 - 5 } & $N$ & $\%$ & $N$ & $\%$ \\
\hline No Formal Schooling & 6 & 1.9 & 14 & 4.6 \\
Elementary School & 18 & 5.8 & 37 & 12.1 \\
Vocational Studies & 16 & 5.2 & 17 & 5.6 \\
High School & 64 & 20.8 & 99 & 32.4 \\
Bachelors & 112 & 36.4 & 99 & 32.4 \\
Masters/Graduate Certificate & 65 & 21.1 & 30 & 9.8 \\
Doctorate & 27 & 8.8 & 10 & 3.3 \\
\hline
\end{tabular}

Participants in the study were asked to report if they had travelled internationally prior to attending West Virginia University. They were also asked to indicate if they were the first family member to study outside their home country and if they were also the first to study at WVU. One hundred and forty-nine (48.1\%) of the respondents reported that they had travelled internationally prior to attending West Virginia University, 195 $(63.5 \%)$ of the respondents stated they were the first member of their family to study outside their home country, while $266(86.9 \%)$ of those who responded stated that they were the first in their family to study at WVU (see Table 3). 
Table 3

Respondents’ International Travel and International Study Exposure

\begin{tabular}{lcc}
\hline & $N$ & $\%$ \\
\hline Traveled internationally prior to attending WVU & 149 & 48.1 \\
First family member to study outside your home country & 195 & 63.5 \\
First family member to study at WVU & 266 & 86.9 \\
\hline
\end{tabular}

WVU International students were asked to indicate how many months they had studied in the United States and for how long in months they had been studying at WVU. The responses ranged from two to 120 months for the duration of their study in the United States, with the average length of study being 29.91 months $(S D=22.69)$. When respondents were asked to report how long they had studied at West Virginia, their responses ranged from two to 96 months, with the mean duration of study at WVU being 25.18 months $(S D=18.02)$ (see Table 4$)$.

Table 4

Duration of Study in the United States and at WVU in Months

\begin{tabular}{lcccc}
\hline & $M$ & $S D$ & Min & Max \\
\hline $\begin{array}{l}\text { How long have you been } \\
\text { studying in the United States }\end{array}$ & 29.91 & 22.69 & 2.00 & 120.00 \\
$\begin{array}{l}\text { How long have you been } \\
\text { studying at WVU }\end{array}$ & 25.18 & 18.02 & 2.00 & 96.00 \\
\hline
\end{tabular}

Participants were asked to indicate the highest level of education they attained in their home countries before coming to WVU. Forty-six (15.3\%) of the respondents stated that the highest education they attained before leaving their home country was a high 
school diploma, 27 (9\%) of the respondents stated they had attained some college education, while 154 (51.2\%) of the respondents reported they completed a college degree before leaving their home countries to study at WVU. Sixty-two (20.6\%) of the respondents stated they had a post graduate degree and $12(4 \%)$ of the respondents stated they had other degrees before leaving their countries. When participants were asked to indicate their academic status at WVU, $12(3.9 \%)$ of the respondents stated they were freshmen and $12(3.9 \%)$ stated they were juniors. Nine (3\%) of the respondents stated they were sophomores, $17(5.6 \%)$ reported they were seniors, $140(45.9 \%)$ respondents stated they were master's students, $113(37 \%)$ were doctorate students and $2(.7 \%)$ of the respondents stated they were post doctoral students (see Table 5).

Participants were asked to indicate the college at which they were enrolled at West Virginia University. One hundred and eighteen (39.5\%) of the respondents indicated they were enrolled at WVU's College of Engineering and Mineral Resources, $67(22.4 \%)$ respondents were enrolled in the Eberly College of Arts and Sciences and 38 (12.7\%) respondents were from the Davis College of Agriculture, Forestry and Consumer Sciences. Twenty-two (7.4\%) of the respondents were enrolled at WVU's College of Business and Economics, 20 (6.7\%) respondents were in the School of Medicine while 16 (5.4\%) respondents were enrolled in the College of Human Resources and Education. Seven (2.3\%) respondents were from the School of Physical Education and four (1.3\%) respondents were enrolled at WVU's College of Creative Arts. There were two (0.7\%) respondents each from the Schools of Dentistry, Journalism and Nursing, while there was one (0.3) respondent from the College of Law (see Table 6). 
Table 5

Highest Education Level Attained in Home Country \& Academic Status at WVU

\begin{tabular}{lcc}
\hline & $N$ & $\%$ \\
\hline Highest Education Level Attained in Home Country & & \\
High school graduate & 46 & 15.3 \\
Some college & 27 & 9.0 \\
College graduate & 154 & 51.2 \\
Post graduate & 62 & 20.6 \\
Other & 12 & 4.0 \\
Current Academic Status at WVU & & 3.9 \\
Freshman & 12 & 3.9 \\
Junior & 12 & 3.0 \\
Sophomore & 9 & 5.6 \\
Senior & 113 & 45.9 \\
Masters & 140 & 37.0 \\
Doctorate & 2 & \\
Post Doctorate & 17 & \\
\hline
\end{tabular}


Table 6

Distribution of Respondents by Colleges across WVU

\begin{tabular}{lcc}
\hline & $N$ & $\%$ \\
\hline College of Engineering and Mineral Resources & 118 & 39.5 \\
Eberly College of Arts and Sciences & 67 & 22.4 \\
Davis College of Agriculture, Forestry and Consumer Sciences & 38 & 12.7 \\
College of Business and Economics & 22 & 7.4 \\
School of Medicine & 20 & 6.7 \\
College of Human Resources and Education & 16 & 5.4 \\
School of Physical Education & 7 & 2.3 \\
College of Creative Arts & 4 & 1.3 \\
School of Dentistry & 2 & 0.7 \\
School of Journalism & 2 & 0.7 \\
School of Nursing & 2 & 0.7 \\
College of Law & 2 & 0.3 \\
\hline
\end{tabular}

The international students were asked to indicate if they were on graduate assistantships at WVU. Of the respondents, 193 (63.1\%) reported that they were beneficiaries of WVU graduate assistantships (see Table 7).

Table 7

Respondents benefiting from WVU Graduate Assistantships

\begin{tabular}{lcc}
\hline & $N$ & $\%$ \\
\hline Graduate assistantship at WVU & 193 & 63.1 \\
\hline
\end{tabular}


The international students were asked to inidcate their country of origin. Seventyseven percent $(26 \%)$ of the respondents were from India, $43(14.5 \%)$ of the respondents were from China, $13(4.4 \%)$ reported they were from Colombia, while $11(3.7 \%)$ stated their country of origin was Nigeria. Eight (2.7\%) respondents were from Saudi Arabia and eight $(2.7 \%)$ were from Turkey. There were seven $(2.4 \%)$ respondents each from Germany, Iran and Nepal, while there were six (2\%) respondents from Ghana and six (2\%) respondents from Kenya. One hundred and three (34.2\%) respondents reported other countries as their country of origin (see Appendix D).

Table 8

Distribution of Respondents by Countries of Origin

\begin{tabular}{|c|c|c|}
\hline & $N$ & $\%$ \\
\hline India & 77 & 26.0 \\
\hline China & 43 & 14.5 \\
\hline Colombia & 13 & 4.4 \\
\hline Nigeria & 11 & 3.7 \\
\hline Saudi Arabia & 8 & 2.7 \\
\hline Turkey & 8 & 2.7 \\
\hline Germany & 7 & 2.4 \\
\hline Iran & 7 & 2.4 \\
\hline Nepal & 7 & 2.4 \\
\hline Ghana & 6 & 2.0 \\
\hline Kenya & 6 & 2.0 \\
\hline Others* & 103 & 34.2 \\
\hline
\end{tabular}

*(see Appendix D for full country listing) 
Participants were asked to report the sources of information for studying at WVU. Of the 325 respondents, 17 (5.23\%) students stated that they received information about study opportunities in the United States through college recruitment fairs, $26(8 \%)$ of the respondents reported they received information about studying in the United States from media advertisements, 92 (28.31\%) indicated recommendations from relatives, while 233 (71.69\%) reported the Internet as their source of information about study opportunities in the United States. Sixty (18.46\%) of the 325 respondents stated that schools in their home countries informed them about studying in the United States, 25 (7.69\%) of the international students who responded indicated the United States' Embassy in their home country was a source of information about studying in the United States. Thirty-eight $(11.69 \%)$ of the respondents indicated a visit abroad prior to attending college was their source of information for studying in the United States (see Table 9).

Table 9

Sources of Information about Studying in the United States

\begin{tabular}{lcc}
\hline & $N$ & $\%$ \\
\hline College recruitment fair & 17 & 5.23 \\
Media advertisement & 26 & 8.00 \\
Recommendation from relatives & 92 & 28.31 \\
Internet & 233 & 71.69 \\
Schools in home country & 60 & 18.46 \\
United States Embassy & 25 & 7.69 \\
Visits abroad prior to college & 38 & 11.69 \\
\hline
\end{tabular}




\section{Motivations for Studying at West Virginia University}

Participants in this study were asked to rate 21 attitudinal statements about their motivations for studying at West Virginia University, using a six-point Likert scale, ranging from strongly agree $=6$, agree $=5$, agree slightly $=4$, disagree slightly $=3$, disagree $=2$ to strongly disagree $=1$.

WVU International students were asked to respond to the statement, "I chose to study in the United States for its reputation for high quality teaching." Seven respondents $(2.2 \%)$ strongly disagreed with this statement, 11 respondents $(3.4 \%)$ disagreed with the statement, and four respondents (1.2\%) slightly disagreed with the statement. Forty-one individuals (12.7\%) slightly agreed, 132 respondents (40.7\%) agreed and 122 (37.7\%) strongly agreed, while seven respondents (2.2\%) regarded the statement as not applicable to them (see Table 10).

Participants in this study were asked to respond to the statement, "The United States offers better teaching aids than I could have found in my home country." Fifteen respondents $(4.7 \%)$ strongly disagreed with this statement, 16 respondents $(5.0 \%)$ disagreed with the statement, and 30 respondents (9.3\%) slightly disagreed with the statement. Forty-five individuals (14.0\%) slightly agreed, 93 respondents $(28.9 \%)$ agreed and $118(36.6 \%)$ strongly agreed, while 5 respondents $(1.6 \%)$ regarded the statement as not applicable to them (see Table 10).

The participants in the survey were asked to respond to the statement, "I chose WVU because the school offered me a scholarship to pursue my degree." Thirty-six respondents (11.1\%) strongly disagreed with this statement, 33 respondents $(10.2 \%)$ respondents disagreed with the statement, and 11 respondents (3.4\%) slightly disagreed 
with the statement. Twenty-five individuals (7.7\%) slightly agreed, 74 respondents $(22.9 \%)$ agreed and $116(35.9 \%)$ strongly agreed, while $28(8.7 \%)$ respondents regarded the statement as not applicable to them (see Table 10).

Participants in this study were asked to respond to the statement, "I chose to study at WVU because the admission process was easy for me.” Twenty-four respondents (7.5\%) strongly disagreed with this statement, 35 respondents (10.9\%) respondents disagreed with the statement, and another 35 respondents (10.9\%) also slightly disagreed with the statement. Seventy-two individuals (22.4\%) slightly agreed, 92 respondents (28.6\%) agreed and $42(13 \%)$ strongly agreed, while 22 respondents $(6.8 \%)$ regarded the statement as not applicable to them (see Table 10).

Participants were asked to respond to the statement, "The positive level of multicultural diversity was a factor in me choosing to study at WVU.” Twenty-eight respondents (8.8\%) strongly disagreed with this statement, 42 respondents $(13.1 \%)$ respondents disagreed with the statement, and 41 respondents (12.8\%) slightly disagreed with the statement. Eighty-seven individuals (27.2\%) slightly agreed, 71 respondents (22.2\%) agreed and $29(9.1 \%)$ strongly agreed, while 22 respondents $(6.9 \%)$ regarded the statement as not applicable to them (see Table 10).

WVU International students were asked to respond to the statement, "I chose to attend WVU in order to be closer to my family members here." One hundred and seventeen respondents (36.2\%) strongly disagreed with this statement, 53 respondents (16.4\%) respondents disagreed with the statement, and 12 respondents (3.7\%) slightly disagreed with the statement. Thirteen individuals (4.0\%) slightly agreed, 32 respondents 
(4.0\%) agreed and $32(9.9 \%)$ strongly agreed, while 61 respondents $(18.9 \%)$ regarded the statement as not applicable to them (see Table 10).

Participants were asked to respond to the statement, "WVU is well advertised in my home country." One hundred and forty respondents (43.5\%) strongly disagreed with this statement, 77 respondents (23.9\%) respondents disagreed with the statement, and 25 respondents (7.8\%) slightly disagreed with the statement. Thirty-three students $(10.2 \%)$ slightly agreed, 14 respondents (4.3\%) agreed and $6(1.9 \%)$ strongly agreed, while 27 respondents (8.4\%) regarded the statement as not applicable to them (see Table 10).

WVU International students were asked to respond to the statement, "WVU offers a broad range of courses of interest to my major." Sixteen respondents (5.0\%) strongly disagreed with this statement, 10 respondents (3.1\%) respondents disagreed with the statement, and 33 respondents (10.3\%) slightly disagreed with the statement. Seventyfive individuals (23.4\%) slightly agreed, 125 respondents (39.1\%) agreed and $53(16.6 \%)$ strongly agreed, while eight respondents (2.5\%) regarded the statement as not applicable to them (see Table 10).

Participants were asked to respond to the statement, "Graduates with degrees earned in the United States are highly respected in my home country." Two respondents $(0.6 \%)$ strongly disagreed with this statement, five $(1.6 \%)$ respondents disagreed with the statement, and four respondents (1.2\%) slightly disagreed with the statement. Sixty individuals (18.6\%) slightly agreed, 128 respondents (39.8\%) agreed and 116 (36.0\%) strongly agreed, while seven respondents (2.2\%) regarded the statement as not applicable to them (see Table 10). 
The international students were asked to respond to the statement, "Studying in the United States provides me a global perspective of my career." Two respondents $(0.6 \%)$ strongly disagreed with this statement, six respondents (1.9\%) respondents disagreed with the statement, and four respondents (1.2\%) slightly disagreed with the statement. Sixty individuals (18.6\%) slightly agreed, 128 respondents (39.8\%) agreed and $116(36 \%)$ strongly agreed, while two respondents $(0.6 \%)$ regarded the statement as not applicable to them (see Table 10).

Participants were asked to respond to the statement, "Negative experiences with higher education in my home country influenced my decision to study in the United States." Seventy-seven respondents (24.1\%) strongly disagreed with this statement, 71 respondents $(22.3 \%)$ respondents disagreed with the statement, and 29 respondents (9.1\%) slightly disagreed with the statement. Thirty-three individuals (10.3\%) slightly agreed, 53 respondents (16.6\%) agreed and $37(11.6 \%)$ strongly agreed, while 19 respondents (6.0\%) regarded the statement as not applicable to them (see Table 10).

Participants were also asked to respond to the statement, "I selected WVU for its reputation for being responsive to students needs.” Twenty-one respondents (6.5\%) strongly disagreed with this statement, 47 respondents (14.6\%) respondents disagreed with the statement, and 27 respondents (8.4\%) slightly disagreed with the statement. Seventy-nine students (24.6\%) slightly agreed, 81 respondents (25.2\%) agreed and 16 $(5.0 \%)$ strongly agreed, while 50 respondents $(15.6 \%)$ regarded the statement as not applicable to them (see Table 10).

WVU International students were asked to respond to the statement, "My relatives persuaded me to choose WVU." Seventy-eight respondents (24.5\%) strongly disagreed 
with this statement, 74 respondents $(23.2 \%)$ respondents disagreed with the statement, and 12 respondents (3.8\%) slightly disagreed with the statement. Thirty-one individuals (9.7\%) slightly agreed, 38 respondents (11.9\%) agreed and 26 (8.2\%) students strongly agreed, while 60 respondents (18.8\%) regarded the statement as not applicable to them (see Table 10).

Participants were asked to respond to the statement, "Low racial discrimination at WVU was important in my choice." Forty respondents (12.5\%) strongly disagreed with this statement, 49 respondents $(15.3 \%)$ respondents disagreed with the statement, and 30 respondents (9.4\%) slightly disagreed with the statement. Forty-eight individuals (15\%) slightly agreed, 71 respondents (22.2\%) agreed and 27 (8.4\%) strongly agreed, while 55 respondents (17.2\%) regarded the statement as not applicable to them (see Table 10).

The International students were asked to respond to the statement, "Prominent individuals in my home country attended WVU." Eighty - respondents (25.2\%) strongly disagreed with this statement, 84 respondents (26.4\%) respondents disagreed with the statement, and 36 respondents (11.3\%) slightly disagreed with the statement. Twenty individuals (6.3\%) slightly agreed, 30 respondents (9.4\%) agreed and 18 (5.7\%) strongly agreed, while 50 respondents (15.7\%) regarded the statement as not applicable to them (see Table 10).

Participants in this study were asked to respond to the statement, "A degree earned in the United States is preferred for high profile employment in my home country." Ten respondents (3.1\%) strongly disagreed with this statement, 18 respondents (5.6\%) respondents disagreed with the statement, and 20 respondents (6.3\%) slightly disagreed with the statement. Sixty-five individuals (20.4\%) slightly agreed, 112 
respondents (35.1\%) agreed and $90(28.2 \%)$ strongly agreed, while four respondents $(1.3 \%)$ regarded the statement as not applicable to them (see Table 10$)$.

The international students were asked to respond to the statement, "A low cost of living inspired my choice to study at WVU." Thirty-one respondents (9.7\%) strongly disagreed with this statement, 37 respondents $(11.6 \%)$ respondents disagreed with the statement, and forty respondents (12.5\%) slightly disagreed with the statement. Seventysix individuals (23.8\%) slightly agreed, 79 respondents (24.7\%) agreed and $37(11.6 \%)$ strongly agreed, while 20 respondents $(6.3 \%)$ regarded the statement as not applicable to them (see Table 10).

The students were asked to respond to the statement, "I chose to study in the United States because of many career opportunities available in the United States." Thirteen respondents $(4.1 \%)$ strongly disagreed with this statement, 35 respondents (11\%) respondents disagreed with the statement, and 20 respondents $(6.3 \%)$ slightly disagreed with the statement. Fifty-three individuals (16.7\%) slightly agreed, 88 respondents $(27.7 \%)$ agreed and $93(29.2 \%)$ strongly agreed, while 16 respondents $(5 \%)$ regarded the statement as not applicable to them (see Table 10).

WVU International students were asked to respond to the statement, "I chose to study in the United States due to my parents' preference for a degree from the United States." Sixty-seven respondents (21.1\%) strongly disagreed with this statement, 61 respondents $(19.2 \%)$ respondents disagreed with the statement, and 33 respondents $(10.4 \%)$ slightly disagreed with the statement. Thirty-four individuals (10.7\%) slightly agreed, 59 respondents (18.6\%) agreed and 22 (6.9\%) strongly agreed, while 42 respondents (13.2\%) regarded the statement as not applicable to them (see Table 10). 
The international students were also asked to respond to the statement, "I chose WVU because of the positive recommendations I got from people who have attended WVU.” Twenty-two respondents (6.9\%) strongly disagreed with this statement, 34 respondents $(10.6 \%)$ respondents disagreed with the statement, and 14 respondents (4.4\%) slightly disagreed with the statement. Sixty-six individuals (20.6\%) slightly agreed, 66 respondents (20.6\%) agreed and 80 (25\%) strongly agreed, while 60 respondents (18.8\%) regarded the statement as not applicable to them (see Table 10).

The participants in the study were asked to respond to the statement, "Negative factors with higher education in my home country influenced my decision to study in the United States." Sixty-seven respondents (21.0\%) strongly disagreed with this statement, 64 respondents (20.1\%) respondents disagreed with the statement, and 23 respondents (7.2\%) slightly disagreed with the statement. Fifty-seven individuals (17.9\%) slightly agreed, 50 respondents (15.7\%) agreed and 35 (11\%) strongly agreed, while 23 respondents (7.2\%) regarded the statement as not applicable to them (see Table 10). 
Table 10

Motivations for Studying at West Virginia University

\begin{tabular}{|c|c|c|c|c|c|c|c|c|c|c|c|c|c|c|}
\hline & \multicolumn{2}{|c|}{$\begin{array}{c}\text { Not } \\
\text { Applicable }\end{array}$} & \multicolumn{2}{|c|}{$\begin{array}{l}\text { Strongly } \\
\text { Disagree }\end{array}$} & \multicolumn{2}{|c|}{ Disagree } & \multicolumn{2}{|c|}{$\begin{array}{l}\text { Disagree } \\
\text { Slightly }\end{array}$} & \multicolumn{2}{|c|}{$\begin{array}{l}\text { Agree } \\
\text { Slightly }\end{array}$} & \multicolumn{2}{|c|}{ Agree } & \multicolumn{2}{|c|}{$\begin{array}{l}\text { Strongly } \\
\text { Agree }\end{array}$} \\
\hline & $N$ & $\%$ & $N$ & $\%$ & $N$ & $\%$ & $N$ & $\%$ & $N$ & $\%$ & $N$ & $\%$ & $N$ & $\%$ \\
\hline $\begin{array}{l}\text { Reputation for high quality } \\
\text { teaching }\end{array}$ & 7 & 2.2 & 7 & 2.2 & 11 & 3.4 & 4 & 1.2 & 41 & 12.7 & 132 & 40.7 & 122 & 37.7 \\
\hline $\begin{array}{l}\text { Better teaching aids than I could } \\
\text { have found in my home country }\end{array}$ & 5 & 1.6 & 15 & 4.7 & 16 & 5.0 & 30 & 9.3 & 45 & 14.0 & 93 & 28.9 & 118 & 36.6 \\
\hline $\begin{array}{l}\text { Offered a scholarship to pursue my } \\
\text { degree }\end{array}$ & 28 & 8.7 & 36 & 11.1 & 33 & 10.2 & 11 & 3.4 & 25 & 7.7 & 74 & 22.9 & 116 & 35.9 \\
\hline $\begin{array}{l}\text { Admission process was easy for } \\
\text { me }\end{array}$ & 22 & 6.8 & 24 & 7.5 & 35 & 10.9 & 35 & 10.9 & 72 & 22.4 & 92 & 28.6 & 42 & 13.0 \\
\hline $\begin{array}{l}\text { Positive level of multicultural } \\
\text { diversity }\end{array}$ & 22 & 6.9 & 28 & 8.8 & 42 & 13.1 & 41 & 12.8 & 87 & 27.2 & 71 & 22.2 & 29 & 9.1 \\
\hline Closer to my family members here & 61 & 18.9 & 117 & 36.2 & 53 & 16.4 & 12 & 3.7 & 13 & 4.0 & 32 & 9.9 & 35 & 10.8 \\
\hline $\begin{array}{l}\text { WVU is well advertised in my } \\
\text { home country }\end{array}$ & 27 & 8.4 & 140 & 43.5 & 77 & 23.9 & 25 & 7.8 & 33 & 10.2 & 14 & 4.3 & 6 & 1.9 \\
\hline $\begin{array}{l}\text { WVU offers a broad range of } \\
\text { courses in my major }\end{array}$ & 8 & 2.5 & 16 & 5.0 & 10 & 3.1 & 33 & 10.3 & 75 & 23.4 & 125 & 39.1 & 53 & 16.6 \\
\hline
\end{tabular}


Table 10 (continued)

Motivations for Studying at West Virginia University

\begin{tabular}{|c|c|c|c|c|c|c|c|c|c|c|c|c|c|c|}
\hline & \multicolumn{2}{|c|}{$\begin{array}{c}\text { Not } \\
\text { Applicable }\end{array}$} & \multicolumn{2}{|c|}{$\begin{array}{l}\text { Strongly } \\
\text { Disagree }\end{array}$} & \multicolumn{2}{|c|}{ Disagree } & \multicolumn{2}{|c|}{$\begin{array}{l}\text { Disagree } \\
\text { Slightly }\end{array}$} & \multicolumn{2}{|c|}{$\begin{array}{l}\text { Agree } \\
\text { Slightly }\end{array}$} & \multicolumn{2}{|c|}{ Agree } & \multicolumn{2}{|c|}{$\begin{array}{l}\text { Strongly } \\
\text { Agree }\end{array}$} \\
\hline & $N$ & $\%$ & $N$ & $\%$ & $N$ & $\%$ & $N$ & $\%$ & $N$ & $\%$ & $N$ & $\%$ & $N$ & $\%$ \\
\hline $\begin{array}{l}\text { United States Degrees are highly } \\
\text { respected in my home country }\end{array}$ & 7 & 2.2 & 2 & .6 & 5 & 1.6 & 4 & 1.2 & 60 & 18.6 & 128 & 39.8 & 116 & 36.0 \\
\hline $\begin{array}{l}\text { United States provides me a global } \\
\text { perspective of my career }\end{array}$ & 2 & .6 & 2 & .6 & 6 & 1.9 & 3 & .9 & 25 & 7.9 & 142 & 44.9 & 136 & 43.0 \\
\hline $\begin{array}{l}\text { Negative experiences with higher } \\
\text { education in my home country }\end{array}$ & 19 & 6.0 & 77 & 24.1 & 71 & 22.3 & 29 & 9.1 & 33 & 10.3 & 53 & 16.6 & 37 & 11.6 \\
\hline $\begin{array}{l}\text { Reputation of WVU for being } \\
\text { responsive to students needs }\end{array}$ & 50 & 15.6 & 21 & 6.5 & 47 & 14.6 & 27 & 8.4 & 79 & 24.6 & 81 & 25.2 & 16 & 5.0 \\
\hline $\begin{array}{l}\text { My relatives persuaded me to } \\
\text { choose WVU }\end{array}$ & 60 & 18.8 & 78 & 24.5 & 74 & 23.2 & 12 & 3.8 & 31 & 9.7 & 38 & 11.9 & 26 & 8.2 \\
\hline $\begin{array}{l}\text { Low racial discrimination at WVU } \\
\text { was important in my choice }\end{array}$ & 55 & 17.2 & 40 & 12.5 & 49 & 15.3 & 30 & 9.4 & 48 & 15.0 & 71 & 22.2 & 27 & 8.4 \\
\hline $\begin{array}{l}\text { Prominent individuals in my home } \\
\text { country attended WVU }\end{array}$ & 50 & 15.7 & 80 & 25.2 & 84 & 26.4 & 36 & 11.3 & 20 & 6.3 & 30 & 9.4 & 18 & 5.7 \\
\hline
\end{tabular}


Table 10 (continued)

Motivations for Studying at West Virginia University

\begin{tabular}{|c|c|c|c|c|c|c|c|c|c|c|c|c|c|c|}
\hline & \multicolumn{2}{|c|}{$\begin{array}{c}\text { Not } \\
\text { Applicable }\end{array}$} & \multicolumn{2}{|c|}{$\begin{array}{l}\text { Strongly } \\
\text { Disagree }\end{array}$} & \multicolumn{2}{|c|}{ Disagree } & \multicolumn{2}{|c|}{$\begin{array}{l}\text { Disagree } \\
\text { Slightly }\end{array}$} & \multicolumn{2}{|c|}{$\begin{array}{l}\text { Agree } \\
\text { Slightly }\end{array}$} & \multicolumn{2}{|c|}{ Agree } & \multicolumn{2}{|c|}{$\begin{array}{l}\text { Strongly } \\
\text { Agree }\end{array}$} \\
\hline & $N$ & $\%$ & $N$ & $\%$ & $N$ & $\%$ & $N$ & $\%$ & $N$ & $\%$ & $N$ & $\%$ & $N$ & $\%$ \\
\hline $\begin{array}{l}\text { A degree earned in the United } \\
\text { States is preferred for high profile } \\
\text { employment }\end{array}$ & 4 & 1.3 & 10 & 3.1 & 18 & 5.6 & 20 & 6.3 & 65 & 20.4 & 112 & 35.1 & 90 & 28.2 \\
\hline $\begin{array}{l}\text { A low cost of living inspired my } \\
\text { choice to study at WVU }\end{array}$ & 20 & 6.3 & 31 & 9.7 & 37 & 11.6 & 40 & 12.5 & 76 & 23.8 & 79 & 24.7 & 37 & 11.6 \\
\hline $\begin{array}{l}\text { Numerous career opportunities } \\
\text { available in the United States }\end{array}$ & 16 & 5.0 & 13 & 4.1 & 35 & 11.0 & 20 & 6.3 & 53 & 16.7 & 88 & 27.7 & 93 & 29.2 \\
\hline $\begin{array}{l}\text { Parents preference for a degree } \\
\text { from the United States }\end{array}$ & 42 & 13.2 & 67 & 21.1 & 61 & 19.2 & 33 & 10.4 & 34 & 10.7 & 59 & 18.6 & 22 & 6.9 \\
\hline $\begin{array}{l}\text { Positive recommendations from } \\
\text { people who have attended WVU }\end{array}$ & 44 & 13.8 & 22 & 6.9 & 34 & 10.6 & 14 & 4.4 & 66 & 20.6 & 80 & 25.0 & 60 & 18.8 \\
\hline $\begin{array}{l}\text { Negative factors with higher } \\
\text { education in my home country }\end{array}$ & 23 & 7.2 & 67 & 21.0 & 64 & 20.1 & 23 & 7.2 & 57 & 17.9 & 50 & 15.7 & 35 & 11.0 \\
\hline
\end{tabular}




\section{Factors Influencing the Decision to Study at WVU}

Participants in this study were asked to respond to statements about the factors that possibly influenced their decision to study at WVU. Eleven attitudinal statements about factors that influence international students' study decision at West Virginia University were also rated on a six-point Likert scale.

The participants in the study were asked to indicate their level of agreement to the item, "I decided to study at WVU because of uncertainty of the length of study at institutions in my home country." Eighty-five respondents (27\%) strongly disagreed with this statement, 81 respondents $(25.7 \%)$ respondents disagreed with the statement, and 46 respondents (14.6\%) slightly disagreed with the statement. Thirty-one individuals (9.8\%) slightly agreed, 19 respondents (6\%) agreed and $22(7 \%)$ strongly agreed, while 31 respondents (9.8\%) regarded the statement as not applicable to them (see Table 11).

WVU international students were asked to respond to the statement, "I decided to study at WVU because of difficulties with gaining admission into universities in my home country." One hundred respondents (31.5\%) strongly disagreed with this statement, 86 respondents (27.1\%) respondents disagreed with the statement, and 38 respondents (12\%) also slightly disagreed with the statement. Nineteen individuals (6\%) slightly agreed, 35 respondents (11\%) agreed and $16(5 \%)$ strongly agreed, while 23 respondents (7.2\%) regarded the statement as not applicable to them (see Table 11).

The participants in the study were asked to respond to the statement, "I decided to study at WVU because of unemployment rates of graduates in my home country." Fiftyfive respondents (17.4\%) strongly disagreed with this statement, 56 respondents (17.7\%) respondents disagreed with the statement, and 32 respondents (10.1\%) slightly disagreed 
with the statement. Fifty-four individuals (17.1\%) slightly agreed, 60 respondents (19\%) agreed and $34(10.8 \%)$ strongly agreed, while 25 respondents $(7.9 \%)$ regarded the statement as not applicable to them (see Table 11).

The participants in the study were asked to rate their agreement to the factor, "I decided to study at WVU because of availability of financial aid at WVU." Nineteen respondents $(6 \%)$ strongly disagreed with this statement, 30 respondents $(9.4 \%)$ respondents disagreed with the statement, and 18 respondents $(5.7 \%)$ slightly disagreed with the statement. Forty-nine individuals (15.4\%) slightly agreed, 76 respondents (23.9\%) agreed and 99 (31.1\%) strongly agreed, while 27 respondents $(8.5 \%)$ regarded the statement as not applicable to them (see Table 11).

The participants in the study were asked to respond to the statement, "I decided to study at WVU because of high quality of teaching at WVU." Eight respondents $(2.5 \%)$ strongly disagreed with this statement, 14 respondents $(4.4 \%)$ respondents disagreed with the statement, and 23 respondents (7.3\%) slightly disagreed with the statement. Ninetyone students (28.7\%) slightly agreed, 128 respondents (40.4\%) agreed and $39(12.3 \%)$ strongly agreed, while 14 respondents (4.4\%) regarded the statement as not applicable to them (see Table 11).

The participants in the study were asked to respond to the statement, "I decided to study at WVU because of higher demand for international degrees by employers in my home country." Fourteen respondents (4.4\%) strongly disagreed with this statement, 25 respondents $(7.9 \%)$ respondents disagreed with the statement, and 26 respondents $(8.2 \%)$ slightly disagreed with the statement. Eighty-five individuals (26.8\%) slightly agreed, 88 
respondents (27.8\%) agreed and $62(19.6 \%)$ strongly agreed, while 17 respondents (5.4\%) regarded the statement as not applicable to them (see Table 11).

The participants in the study were asked to respond to the statement, "I decided to study at WVU because of America's language similarities with my home country." Eight -eight respondents (27.8\%) strongly disagreed with this statement, 55 respondents (17.4\%) disagreed with the statement, and 20 respondents (6.3\%) slightly disagreed with the statement. Forty - two individuals (13.3\%) slightly agreed, 61 respondents (19.3\%) agreed and 25(7.9\%) strongly agreed, while 25 respondents (7.9\%) regarded the statement as not applicable to them (see Table 11).

Respondents were asked to respond to the statement, "I decided to study at WVU because of positive recommendations received from students studying outside my home country." Seventeen respondents (5.4\%) strongly disagreed with this statement, 26 respondents $(8.2 \%)$ respondents disagreed with the statement, and 23 respondents $(7.3 \%)$ slightly disagreed with the statement. Seventy - seven individuals (24.4\%) slightly agreed, 101 respondents (32\%) agreed and $41(13 \%)$ strongly agreed, while 31 respondents (9.8\%) regarded the statement as not applicable to them (see Table 11).

The participants in the study were asked to respond to the statement, "I decided to study at WVU because of student recruitment programs organized by United States institutions in my home country." Seventy-four respondents (23.3\%) strongly disagreed with this statement, 74 respondents $(23.3 \%)$ respondents also disagreed with the statement, and 29 respondents (9.1\%) slightly disagreed with the statement. Thirty-nine individuals (12.3\%) slightly agreed, 25 respondents (7.9\%) agreed and 14 (4.4\%) 
strongly agreed, while 62 of the respondents (19.6\%) regarded the statement as not applicable to them (see Table 11).

WVU international students were also asked to respond to the statement, "I decided to study at WVU because of presence of relatives in the United States." Eightynine respondents (28.3\%) strongly disagreed with this statement, 55 respondents $(17.5 \%)$ respondents disagreed with the statement, and 14 respondents (4.5\%) slightly disagreed with the statement. Thirty-seven individuals (11.8\%) slightly agreed, 30 respondents (9.6\%) agreed and $52(16.6 \%)$ strongly agreed, while 52 respondents (16.6\%) regarded the statement as not applicable to them (see Table 11).

The participants in the study were asked to respond to the statement, "I decided to study at WVU because of prevalence of advanced research techniques at WVU." Twenty-four respondents (7.6\%) strongly disagreed with this statement and some other 24 respondents $(7.6 \%)$ respondents also disagreed with the statement, and 18 respondents (5.7\%) slightly disagreed with the statement. Seventy-two individuals (22.8\%) slightly agreed, 109 respondents (34.5\%) agreed and 44 (13.9\%) strongly agreed, while 25 respondents (7.9\%) regarded the statement as not applicable to them (see Table 11). 
Table 11

Factors Influencing the Decision to Study at WVU

\begin{tabular}{|c|c|c|c|c|c|c|c|c|c|c|c|c|c|c|}
\hline & \multicolumn{2}{|c|}{$\begin{array}{c}\text { Not } \\
\text { Applicable }\end{array}$} & \multicolumn{2}{|c|}{$\begin{array}{l}\text { Strongly } \\
\text { Disagree }\end{array}$} & \multicolumn{2}{|c|}{ Disagree } & \multicolumn{2}{|c|}{$\begin{array}{l}\text { Disagree } \\
\text { Slightly }\end{array}$} & \multicolumn{2}{|c|}{$\begin{array}{c}\text { Agree } \\
\text { Slightly }\end{array}$} & \multicolumn{2}{|c|}{ Agree } & \multicolumn{2}{|c|}{$\begin{array}{l}\text { Strongly } \\
\text { Agree }\end{array}$} \\
\hline & $N$ & $\%$ & $N$ & $\%$ & $N$ & $\%$ & $N$ & $\%$ & $N$ & $\%$ & $N$ & $\%$ & $N$ & $\%$ \\
\hline $\begin{array}{l}\text { Uncertainty of the length of study at } \\
\text { institutions in my home country }\end{array}$ & 31 & 9.8 & 85 & 27.0 & 81 & 25.7 & 46 & 14.6 & 31 & 9.8 & 19 & 6.0 & 22 & 7.0 \\
\hline $\begin{array}{l}\text { Difficulties with gaining admission } \\
\text { into universities in home country }\end{array}$ & 23 & 7.3 & 100 & 31.5 & 86 & 27.1 & 38 & 12.0 & 19 & 6.0 & 35 & 11.0 & 16 & 5.0 \\
\hline $\begin{array}{l}\text { Unemployment rates for graduates in } \\
\text { my home country }\end{array}$ & 25 & 7.9 & 55 & 17.4 & 56 & 17.7 & 32 & 10.1 & 54 & 17.1 & 60 & 19.0 & 34 & 10.8 \\
\hline Availability of WVU financial aid & 27 & 8.5 & 19 & 6.0 & 30 & 9.4 & 18 & 5.7 & 49 & 15.4 & 76 & 23.9 & 99 & 31.1 \\
\hline High quality of teaching at WVU & 14 & 4.4 & 8 & 2.5 & 14 & 4.4 & 23 & 7.3 & 91 & 28.7 & 128 & 40.4 & 39 & 12.3 \\
\hline $\begin{array}{l}\text { Higher demand for international } \\
\text { degrees by employers at home }\end{array}$ & 17 & 5.4 & 14 & 4.4 & 25 & 7.9 & 26 & 8.2 & 85 & 26.8 & 88 & 27.8 & 62 & 19.6 \\
\hline $\begin{array}{l}\text { Language similarities with my home } \\
\text { country }\end{array}$ & 25 & 7.9 & 88 & 27.8 & 55 & 17.4 & 20 & 6.3 & 42 & 13.3 & 61 & 19.3 & 25 & 7.9 \\
\hline $\begin{array}{l}\text { Positive recommendations received } \\
\text { from students outside my country }\end{array}$ & 31 & 9.8 & 17 & 5.4 & 26 & 8.2 & 23 & 7.3 & 77 & 24.4 & 101 & 32.0 & 41 & 13.0 \\
\hline
\end{tabular}


Table 11 (continued)

Factors Influencing the Decision to Study at WVU

\begin{tabular}{|c|c|c|c|c|c|c|c|c|c|c|c|c|c|c|}
\hline & \multicolumn{2}{|c|}{$\begin{array}{c}\text { Not } \\
\text { Applicable }\end{array}$} & \multicolumn{2}{|c|}{$\begin{array}{l}\text { Strongly } \\
\text { Disagree }\end{array}$} & \multicolumn{2}{|c|}{ Disagree } & \multicolumn{2}{|c|}{$\begin{array}{l}\text { Disagree } \\
\text { Slightly }\end{array}$} & \multicolumn{2}{|c|}{$\begin{array}{l}\text { Agree } \\
\text { Slightly }\end{array}$} & \multicolumn{2}{|c|}{ Agree } & \multicolumn{2}{|c|}{$\begin{array}{l}\text { Strongly } \\
\text { Agree }\end{array}$} \\
\hline & $N$ & $\%$ & $N$ & $\%$ & $N$ & $\%$ & $N$ & $\%$ & $N$ & $\%$ & $N$ & $\%$ & $N$ & $\%$ \\
\hline $\begin{array}{l}\text { Student recruitment organized by } \\
\text { United States institutions }\end{array}$ & 62 & 19.6 & 74 & 23.3 & 74 & 23.3 & 29 & 9.1 & 39 & 12.3 & 25 & 7.9 & 14 & 4.4 \\
\hline Relatives in the United States & 52 & 16.6 & 89 & 28.3 & 55 & 17.5 & 14 & 4.5 & 37 & 11.8 & 37 & 11.8 & 30 & 9.6 \\
\hline $\begin{array}{l}\text { Prevalence of advanced research } \\
\text { techniques at WVU }\end{array}$ & 25 & 7.9 & 24 & 7.6 & 24 & 7.6 & 18 & 5.7 & 72 & 22.8 & 109 & 34.5 & 44 & 13.9 \\
\hline Others: & 132 & 78.6 & 4 & 2.4 & 5 & 3.0 & 1 & .6 & 4 & 2.4 & 13 & 7.7 & 9 & 5.4 \\
\hline
\end{tabular}




\section{Constraints Affecting International Students’ Decisions to Study in the United States}

Using a six- point Likert scale, respondents were asked to rate perceived constraints that affected international students' decision to study in the United States. Sixteen attitudinal statements about constraints perceived to affect international students' study decision were rated.

The participants in the study were asked to respond to whether or not, "Difficulties in securing student visa" was perceived as a constraint. Thirteen respondents (4.2\%) strongly disagreed with this statement, 18 respondents (5.8\%) respondents disagreed with the statement, and 15 respondents (4.8\%) slightly disagreed with the statement. Forty students (12.9\%) slightly agreed, 84 respondents (27.1\%) agreed and $132(42.6 \%)$ strongly agreed, while eight respondents $(2.6 \%)$ regarded the constraint as not applicable to them (see Table 12).

WVU international students were asked to respond to whether or not "Visa denials" was perceived as a constraint. Twenty respondents (6.4\%) strongly disagreed with this statement, 25 respondents (8\%) disagreed with the statement, and 17 respondents (5.5\%) slightly disagreed with the statement. Forty individuals (12.9\%) slightly agreed, 89 respondents (28.6\%) agreed and 104 (33.4\%) strongly agreed, while 16 respondents (5.1\%) regarded the statement as not applicable to them (see Table 12).

The participants were also asked to respond to whether or not, "Costs of traveling to attend an institution of higher learning in the United States" was perceived as a constraint. Ten respondents (3.2\%) strongly disagreed with this statement, 12 respondents (3.8\%) respondents disagreed with the statement, and 19 respondents (6.1\%) slightly disagreed with the statement. Fifty-five individuals (17.6\%) slightly agreed, 112 
respondents (35.9\%) agreed and 95 (30.4\%) strongly agreed, while 9 respondents $(2.9 \%)$ regarded the statement as not applicable to them (see Table 12).

The participants were asked to respond to whether or not "Cost of college fees in the United States" was perceived as a constraint. Four respondents (1.3\%) strongly disagreed with this statement, seven respondents $(2.3 \%)$ respondents disagreed with the statement, and seven respondents $(2.3 \%)$ also slightly disagreed with the statement. Forty-three individuals (14.1\%) slightly agreed, 99 respondents (32.4\%) agreed and 133 (43.5\%) strongly agreed, while 13 respondents $(4.2 \%)$ regarded the statement as not applicable to them (see Table 12).

Respondents were asked to indicate their level agreement to whether or "Cost of living in the United States" was perceived as a constraint. Three respondents (1\%) strongly disagreed with this statement, 11 respondents $(3.5 \%)$ respondents disagreed with the statement, and 22 respondents (7\%) slightly disagreed with the statement. Fifty-four individuals (17.3\%) slightly agreed, 117 respondents (37.4\%) agreed and $96(30.7 \%)$ strongly agreed, while 10 respondents (3.2\%) regarded the statement as not applicable to them (see Table 12).

The international students in the study were asked to respond to whether or not, "Lack of available graduate assistantships" was perceived as a constraint. Eleven respondents $(3.5 \%)$ strongly disagreed with this statement, 27 respondents $(8.6 \%)$ respondents disagreed with the statement, and 25 respondents (8\%) slightly disagreed with the statement. Seventy-two individuals (23\%) slightly agreed, 61 respondents (19.5\%) agreed and $90(28.8 \%)$ strongly agreed, while 27 respondents $(8.6 \%)$ regarded the statement as not applicable to them (see Table 12). 
The participants in the study were asked to indicate their level of agreement to, "Lack of awareness about study opportunities" as a constraint. Fourteen respondents (4.6\%) strongly disagreed with this statement, 37 respondents $(12.1 \%)$ respondents disagreed with the statement, and 35 respondents (11.5\%) slightly disagreed with the statement. Seventy-three individuals (23.9\%) slightly agreed, 80 respondents $(26.2 \%)$ agreed and $51(16.7 \%)$ strongly agreed, while 15 respondents (4.9\%) regarded the statement as not applicable to them (see Table 12).

Respondents were also asked to respond to whether or not, "Perceptions about the United States in home country" was perceived as a constraint. Thirty respondents $(9.6 \%)$ strongly disagreed with this statement, 52 respondents $(16.7 \%)$ respondents disagreed with the statement, and 46 respondents (14.8\%) slightly disagreed with the statement. Fifty-nine individuals (19\%) slightly agreed, 79 respondents (25.4\%) agreed and 31 $(10 \%)$ strongly agreed, while 14 respondents $(4.5 \%)$ regarded the statement as not applicable to them (see Table 12).

The participants in the study were asked to indicate their degree of agreement to the statement, "Perceived religious restrictions in the United States" as a constraint. Seventy respondents (22.4\%) strongly disagreed with this statement, 86 respondents $(27.6 \%)$ respondents disagreed with the statement, and 54 respondents $(17.3 \%)$ slightly disagreed with the statement. Thirty-four individuals (10.9\%) slightly agreed, 29 respondents $(9.3 \%)$ agreed and $7(2.2 \%)$ strongly agreed, while 32 respondents $(10.3 \%)$ regarded the statement as not applicable to them (see Table 12).

Participants were asked to indicate their level of agreement to "Transcript evaluation delays" as a constraint. Thirty-seven respondents (11.8\%) strongly disagreed 
with this statement, 74 respondents $(23.6 \%)$ respondents disagreed with the statement, and 68 respondents (21.7\%) slightly disagreed with the statement. Forty-six individuals (14.7\%) slightly agreed, 35 respondents (11.2\%) agreed and 12 (3.8\%) strongly agreed, while 41 respondents (13.1\%) regarded the statement as not applicable to them (see Table 12).

The participants in the study were asked to respond to whether or not, "No testing centers in home country" was perceived as a constraint. Eighty-one respondents (26\%) strongly disagreed with this statement, 103 respondents (33.1\%) respondents disagreed with the statement, and 28 respondents (9\%) slightly disagreed with the statement. Twenty-five individuals (8\%) slightly agreed, 29 respondents (9.3\%) agreed and 11 (3.5\%) strongly agreed while 34 respondents (10.9\%) regarded the statement as not applicable to them (see Table 12).

The international students in the study were also asked to affirm if "Delays in accessing educational transcripts" was a constraint. Forty-nine respondents (15.8\%) strongly disagreed with this statement, 93 respondents (29.9\%) respondents disagreed with the statement, and 41 respondents (13.2\%) slightly disagreed with the statement. Thirty-nine individuals (12.5\%) slightly agreed, 41 respondents (13.2\%) agreed and 17 (5.5\%) strongly agreed while 31 respondents $(10 \%)$ regarded the statement as not applicable to them (see Table 12).

Participants in the study were asked to respond to whether or not the following was perceived as a constraint, "Language barriers." Forty-eight respondents (15.4\%) strongly disagreed with this statement, 60 respondents (19.2\%) respondents disagreed with the statement, and 31 respondents $(9.9 \%)$ slightly disagreed with the statement. 
Seventy-seven individuals (22.4\%) slightly agreed, 62 respondents (19.9\%) agreed and $28(9 \%)$ strongly agreed, while 13 respondents (4.2\%) regarded the statement as not applicable to them (see Table 12).

The WVU international students were also asked to respond to whether or not "Fear of adjusting to unfamiliar weather" was perceived as a constraint. Fifty-five respondents (17.7\%) strongly disagreed with this statement, 82 respondents $(26.5 \%)$ respondents disagreed with the statement, and 38 respondents (12.3\%) slightly disagreed with the statement. Fifty-four individuals (17.4\%) slightly agreed, 50 respondents (16.1\%) agreed and $17(5.5 \%)$ strongly agreed, while 14 respondents $(4.5 \%)$ regarded the statement as not applicable to them (see Table 12).

The study participants were asked to indicate if "Absence of relatives in the United States" was considered a constraint. Forty respondents (12.9\%) strongly disagreed with this statement, 48 respondents (15.4\%) disagreed with the statement, and 38 respondents (12.2\%) slightly disagreed with the statement. Seventy-two individuals (23.2\%) slightly agreed, 66 respondents (21.2\%) agreed and 27 (8.7\%) strongly agreed, while 20 respondents $(6.4 \%)$ regarded the statement as not applicable to them (see Table 12).

The participants were asked to indicate if, "Food and dietary differences" was considered a constraint. Fifty respondents (16.1\%) strongly disagreed with this statement, 69 respondents $(22.2 \%)$ respondents disagreed with the statement, and 49 respondents (15.8\%) slightly disagreed with the statement. Fifty-three individuals (17\%) slightly agreed, 57 respondents (18.3\%) agreed and 16 (5.1\%) strongly agreed, while 17 respondents (5.5\%) regarded the statement as not applicable to them (see Table 12). 
Table 12

\section{Constraints to Study Migration Decision}

\begin{tabular}{|c|c|c|c|c|c|c|c|c|c|c|c|c|c|c|}
\hline & \multicolumn{2}{|c|}{$\begin{array}{c}\text { Not } \\
\text { Applicable }\end{array}$} & \multicolumn{2}{|c|}{$\begin{array}{l}\text { Strongly } \\
\text { Disagree }\end{array}$} & \multicolumn{2}{|c|}{ Disagree } & \multicolumn{2}{|c|}{$\begin{array}{l}\text { Disagree } \\
\text { Slightly }\end{array}$} & \multicolumn{2}{|c|}{$\begin{array}{l}\text { Agree } \\
\text { Slightly }\end{array}$} & \multicolumn{2}{|c|}{ Agree } & \multicolumn{2}{|c|}{$\begin{array}{l}\text { Strongly } \\
\text { Agree }\end{array}$} \\
\hline & $N$ & $\%$ & $N$ & $\%$ & $N$ & $\%$ & $N$ & $\%$ & $N$ & $\%$ & $N$ & $\%$ & $N$ & $\%$ \\
\hline Difficulties in securing visa & 8 & 2.6 & 13 & 4.2 & 18 & 5.8 & 15 & 4.8 & 40 & 12.9 & 84 & 27.1 & 132 & 42.6 \\
\hline Visa denials & 16 & 5.1 & 20 & 6.4 & 25 & 8.0 & 17 & 5.5 & 40 & 12.9 & 89 & 28.6 & 104 & 33.4 \\
\hline $\begin{array}{l}\text { Traveling costs to attend higher } \\
\text { institutions in the United States }\end{array}$ & 9 & 2.9 & 10 & 3.2 & 12 & 3.8 & 19 & 6.1 & 55 & 17.6 & 112 & 35.9 & 95 & 30.4 \\
\hline College fees in the United States & 13 & 4.2 & 4 & 1.3 & 7 & 2.3 & 7 & 2.3 & 43 & 14.1 & 99 & 32.4 & 133 & 43.5 \\
\hline Cost of living in the United States & 10 & 3.2 & 3 & 1.0 & 11 & 3.5 & 22 & 7.0 & 54 & 17.3 & 117 & 37.4 & 96 & 30.7 \\
\hline $\begin{array}{l}\text { Lack of available graduate } \\
\text { assistantships }\end{array}$ & 27 & 8.6 & 11 & 3.5 & 27 & 8.6 & 25 & 8.0 & 72 & 23.0 & 61 & 19.5 & 90 & 28.8 \\
\hline $\begin{array}{l}\text { Lack of awareness about study } \\
\text { opportunities }\end{array}$ & 15 & 4.9 & 14 & 4.6 & 37 & 12.1 & 35 & 11.5 & 73 & 23.9 & 80 & 26.2 & 51 & 16.7 \\
\hline $\begin{array}{l}\text { Perceptions about the United States in } \\
\text { home country }\end{array}$ & 14 & 4.5 & 30 & 9.6 & 52 & 16.7 & 46 & 14.8 & 59 & 19.0 & 79 & 25.4 & 31 & 10.0 \\
\hline
\end{tabular}


Table 12 (continued)

Constraints to Study Migration Decision

\begin{tabular}{|c|c|c|c|c|c|c|c|c|c|c|c|c|c|c|}
\hline & \multicolumn{2}{|c|}{$\begin{array}{c}\text { Not } \\
\text { Applicable }\end{array}$} & \multicolumn{2}{|c|}{$\begin{array}{l}\text { Strongly } \\
\text { Disagree }\end{array}$} & \multicolumn{2}{|c|}{ Disagree } & \multicolumn{2}{|c|}{$\begin{array}{l}\text { Disagree } \\
\text { Slightly }\end{array}$} & \multicolumn{2}{|c|}{$\begin{array}{l}\text { Agree } \\
\text { Slightly }\end{array}$} & \multicolumn{2}{|c|}{ Agree } & \multicolumn{2}{|c|}{$\begin{array}{l}\text { Strongly } \\
\text { Agree }\end{array}$} \\
\hline & $N$ & $\%$ & $N$ & $\%$ & $N$ & $\%$ & $N$ & $\%$ & $N$ & $\%$ & $N$ & $\%$ & $N$ & $\%$ \\
\hline $\begin{array}{l}\text { Perceived religious restrictions in the } \\
\text { United States }\end{array}$ & 32 & 10.3 & 70 & 22.4 & 86 & 27.6 & 54 & 17.3 & 34 & 10.9 & 29 & 9.3 & 7 & 2.2 \\
\hline Transcript evaluation delays & 41 & 13.1 & 37 & 11.8 & 74 & 23.6 & 68 & 21.7 & 46 & 14.7 & 35 & 11.2 & 12 & 3.8 \\
\hline No testing centers in home country & 34 & 10.9 & 81 & 26.0 & 103 & 33.1 & 28 & 9.0 & 25 & 8.0 & 29 & 9.3 & 11 & 3.5 \\
\hline Delays in accessing transcripts & 31 & 10.0 & 49 & 15.8 & 93 & 29.9 & 41 & 13.2 & 39 & 12.5 & 41 & 13.2 & 17 & 5.5 \\
\hline Language barriers & 13 & 4.2 & 48 & 15.4 & 60 & 19.2 & 31 & 9.9 & 70 & 22.4 & 62 & 19.9 & 28 & 9.0 \\
\hline Fear of unfamiliar weather & 14 & 4.5 & 55 & 17.7 & 82 & 26.5 & 38 & 12.3 & 54 & 17.4 & 50 & 16.1 & 17 & 5.5 \\
\hline $\begin{array}{l}\text { Absence of relatives in the United } \\
\text { States }\end{array}$ & 20 & 6.4 & 40 & 12.9 & 48 & 15.4 & 38 & 12.2 & 72 & 23.2 & 66 & 21.2 & 27 & 8.7 \\
\hline Food and dietary differences & 17 & 5.5 & 50 & 16.1 & 69 & 22.2 & 49 & 15.8 & 53 & 17.0 & 57 & 18.3 & 16 & 5.1 \\
\hline Others: & 123 & 82.0 & 7 & 4.7 & 1 & .7 & 2 & 1.3 & 3 & 2.0 & 9 & 6.0 & 5 & 3.3 \\
\hline
\end{tabular}




\section{Level of Availability of Support Services}

Using a 4- point Likert type scale, respondents were asked to rate support services that aid international students' decision to study in the United States. The 4-point Likert type scale, ranging from, "highly available" $=3$, "moderately available" $=2$, "low availability" $=1$, and "not available $=0 "$ " (see Table 13).

Participants in the study were asked to indicate the level of availability of USA College Test preparation in their home countries. Of the respondents, 104 (34\%) rated this as highly available in their home countries, $106(34.6 \%)$ of respondents stated it was moderately available, 69 students $(22.5 \%)$ reported it was low in availability and 27 of the respondents $(8.8 \%)$ indicated College Test preparation for the United States was not available at all in their home countries (see Table 13).

Respondents were asked to rate the availability of USA Financial Aid advising in their home countries. Of the respondents, 34 (11.1\%) rated it as highly available in their home countries, $92(30 \%)$ of respondents stated it was moderately available, 105 students (34.2\%) reported it was low in availability and 76 of the respondents (24.8\%) indicated Financial Aid advising services were not available at all in their home countries (see Table 13).

The participants in the study were asked to indicate the level of availability of student visa advising centers in their home countries. Of the respondents, 70 (23.1\%) rated this as highly available in their home countries, 86 (28.4\%) of respondents stated it was moderately available, 95 students (31.4\%) reported it was low in availability and 52 of the respondents (17.2\%) indicated student visa advising centers were not available at all in their home countries (see Table 13). 
Participants were asked to indicate the level of availability of International English Programs for applicants to United States colleges in their home countries. Of the respondents, $100(32.9 \%)$ rated this as highly available in their home countries, 101 (33.2\%) of respondents stated it was moderately available, 72 students $(23.7 \%)$ reported it was low in availability and 31 of the respondents (10.2\%) indicated International English Programs college applicants to the United States were not available at all in their home countries (see Table 13).

The participants in the study were asked to respond to the level of availability of United States College recruitments in their home countries. Of the respondents, 29 $(9.5 \%)$ rated this as highly available in their home countries, $84(27.5 \%)$ of respondents stated it was moderately available, 117 students $(38.2 \%)$ reported it was low in availability and 76 of the respondents (24.8\%) indicated United States college recruitments were not available at all in their home countries (see Table 13).

The international students in the study were also asked to indicate the level of availability of college admission advertisements in their home countries. Of all respondents, $39(12.8 \%)$ rated this as highly available in their home countries, $74(24.3 \%)$ of respondents stated it was moderately available, 115 students (37.7\%) reported it was low in availability and 77 of the respondents (25.2\%) indicated College Test preparation for the United States was not available at all in their home countries (see Table 13).

Participants in the study were asked to respond to the level of availability of USA Study and Live Abroad Programs in their home countries. Of the respondents, 64 (21\%) rated this as highly available in their home countries, 102 (33.4\%) of respondents stated it was moderately available, 96 students (31.5\%) reported it was low in availability and 43 
of the respondents (14.1\%) indicated USA Study and Live Abroad Programs were not available at all in their home countries (see Table 13).

Participants in this study were asked to the level of availability of United States Embassy College Fairs in their home countries. Thirty-one respondents (10.1\%) rated this as highly available in their home countries, 84 (27.5\%) stated it was moderately available, $120(39.2 \%)$ reported it was low in availability and 71 of the respondents $(23.2 \%)$ indicated it was not available at all in their home countries (see Table 13).

Table 13

Level of Availability of Support Services in Source Countries

\begin{tabular}{lccccccccc}
\hline & $\begin{array}{c}\text { Not } \\
\text { available at } \\
\text { all }\end{array}$ & $\begin{array}{c}\text { Low } \\
\text { availability }\end{array}$ & $\begin{array}{c}\text { Moderately } \\
\text { available }\end{array}$ & $\begin{array}{c}\text { Highly } \\
\text { available }\end{array}$ \\
\cline { 2 - 9 } & $N$ & $\%$ & $N$ & $\%$ & $N$ & $\%$ & $N$ & $\%$ \\
\hline USA College Test preparation & 27 & 8.8 & 69 & 22.5 & 106 & 34.6 & 104 & 34.0 \\
USA Financial Aid Advising & 76 & 24.8 & 105 & 34.2 & 92 & 30.0 & 34 & 11.1 \\
Student Visa Advising Centers & 52 & 17.2 & 95 & 31.4 & 86 & 28.4 & 70 & 23.1 \\
International English Programs for & & & & & & & & \\
applicants to United States colleges & 31 & 10.2 & 72 & 23.7 & 101 & 33.2 & 100 & 32.9 \\
United States college recruitments & 76 & 24.8 & 117 & 38.2 & 84 & 27.5 & 29 & 9.5 \\
College Admission Advertisements & 77 & 25.2 & 115 & 37.7 & 74 & 24.3 & 39 & 12.8 \\
Study and Live Abroad Programs & 43 & 14.1 & 96 & 31.5 & 102 & 33.4 & 64 & 21.0 \\
$\begin{array}{l}\text { United States Embassy College Fairs } \\
\text { Others: }\end{array}$ & 71 & 23.2 & 120 & 39.2 & 84 & 27.5 & 31 & 10.1 \\
\hline & 81 & 75.7 & 10 & 9.3 & 9 & 8.4 & 7 & 6.5 \\
\hline
\end{tabular}




\section{Relationship Between Support Services and Motivation for Studying at WVU}

Aggregate scores for motivations, influences, and constraints were calculated for each respondent by taking the mean of the Likert items on the motivations, influences and constraints sections of the questionnaire, respectively. An aggregate mean score of $3.53(S D=0.86)$ was derived for respondents' motivations to study at WVU. An average aggregate score of $3.25(S D=3.25)$ was obtained for factors influencing their decision to migrate to the United States for a higher education and a aggregate mean score of score $3.63(S D=0.87)$ was obtained for constraints affecting international students' decision to study in the United States. An aggregate score of $1.72(S D=0.68)$ was found for the level of availability of support services in respondents' home countries.

A Pearson's product moment correlation coefficient was calculated to determine an association between the availability of support services to international students and their motivations to study at WVU. The null hypothesis was that there was no association between the availability of support services for international students in their home countries and their motivations to study at WVU. The research hypothesis was there was an association between the level of availability of support services for international students in their home countries and their motivation to study at WVU. The Pearson's $r$ statistical procedure was significant $(r=0.14, \alpha \leq 0.05)$. Hence, the null hypothesis was rejected, while the research hypothesis was accepted. It was concluded that there was a significant low association (Davis, 1971) between the level of availability of support services for international students and their motivation for studying at WVU (see Table 14). 
Table 14

Relationship between Level of Availability of Support Service and Motivation

\begin{tabular}{ll}
\hline Statistics & Value \\
\hline Pearson's R & 0.14 \\
\hline
\end{tabular}

$* \alpha=0.05$ 


\section{CHAPTER V}

Summary, Conclusion and Recommendations

Purpose of the Study

The purpose of this study was to determine factors influencing international students' decisions to enroll at West Virginia University. This research provides insight into the motivators for increasing foreign student enrollment in host institutions, as well

as, challenges and barriers to their enrollment. This information is considered relevant to improving outreach and marketing strategies utilized by United States' host institutions for increasing international student enrollment.

Objectives of the Study

This research was supported by the following questions:

1. What are the perceived constraints to the migration choice of international students?

2. What factors motivate international students to migrate for higher education?

3. What is the level of availability of study abroad support services in their home countries?

4. What are the demographic characteristics of these international students?

\section{Research Hypotheses}

The research posed the following hypotheses for assessing international students' motivations to study in the United States:

$\mathrm{H}_{0}$ : There is no association between the level of availability of support services in home countries and the motivation of international students for studying at West Virginia University. 
$\mathrm{H}_{1}$ : There is a significant association between the level of availability of support services in home countries and the motivation of international students for studying in the West Virginia University.

\section{Limitations of the Study}

The scope of this research is limited to only international students from West Virginia University. Although the generalizability of these findings may extend to universities with similar sizes of international students, caution must be exercised in generalizing these results with different populations, demographics, and geographical locations. The results of this study are not generalizable to all international students in the United States.

\section{Summary}

Approximately $25 \%$ of all respondents were from India and about $15 \%$ of the respondents were from China. Slightly more than half of the respondents were male, and two-fifths of all respondents were between the ages 26 to 30 years. Approximately two thirds of the respondents stated that their fathers had at least a college degree, while slightly less than half of the respondents' mothers attained a college degree. Respondents whose mothers had no formal schooling were about $50 \%$ higher that respondents whose fathers had no formal schooling.

Approximately $48 \%$ of the respondents in this study reported they had travelled internationally prior to attending WVU. About $60 \%$ of international students who participated in the study indicated they were the first member of their family to study outside their home country and a majority of respondents were the first in their family to 
attend WVU. On average, most the respondents had studied in the United States for about 30 months with an average of 25 months having been spent studying at WVU.

Over $80 \%$ of the respondents were graduate students at West Virginia University. A majority of the respondents indicated they had completed a college degree before leaving their home country to study in the United States. Approximately two-thirds of the respondents were benefiting from WVU graduate assistantships. Slightly less than half of the respondents were enrolled in the College of Engineering and Mineral Resources, about a fourth of the respondents were enrolled in Eberly College of Arts and Sciences and over about a tenth of the respondents were from Davis College of Agriculture, Forestry, and Consumer Sciences at West Virginia University.

A majority of the respondents reported the Internet was their source of information about study opportunities in the United States, while college recruitment fairs, media advertisements, and information from the United States Embassy were rated low as sources of information about studying the United States.

Among all items listed as international students' motivations for studying at West Virginia University, the following statements were rated higher: "The United States' reputation for high quality teaching", "The availability of better teaching aids in the United States", "WVU scholarship offers", "WVU's easy admission process", “a broad range of courses", "higher respect for degrees earned in the United States outside", "a global perspective of careers", "preference of high profile employers for United Statesearned degrees", "Lower cost of living at WVU", "career opportunities in the United States" and "positive recommendations from WVU students". 
Nearly all of the respondents agreed to some extent that the United States' had a reputation for high quality teaching, that degrees earned in the United States earn a higher respect at their home country, and that the United States provides a global perspective of their careers. About $80 \%$ of the respondents agreed somewhat that there were better teaching aids available in the United States, that high profile employers in their home countries had a preference for United States- earned degrees, and that WVU offers a broad range of courses of interest to their majors. Nearly $70 \%$ of the respondents affirmed to some extent that career opportunities in the United States motivated them to study at WVU, while about $60 \%$ of the respondents agreed to some degree that they were motivated by WVU's easy admission process, WVU scholarship offers and positive recommendations from WVU students. However, over $75 \%$ of the international students disagreed to some level that WVU was well advertised in their home countries.

Of all items listed as factors perceived to influence international students' decisions to study at WVU, the following had higher levels of agreement; "availability of financial aid at WVU", "high quality of teaching at WVU", "higher demand for international degrees by employers", "positive recommendations from students abroad", and "the prevalence of advanced research techniques at WVU". Nearly $70 \%$ of respondents indicated some level of agreement to the factors, availability of financial aid at WVU, higher demand for international degrees by employers, positive recommendations from students abroad, and the prevalence of advanced research techniques at WVU, as being influential to their decision to study at WVU. Over $80 \%$ of the respondents signified some level of agreement to a higher demand for international degrees by employers as a factor influencing their choice of WVU. However, over $75 \%$ 
of the respondents disagreed to some extent that student recruitment programs by United States institutions influenced their choice of WVU.

The top seven items rated by respondents as highly influential to international students' decisions to study in the United States included, difficulties in securing visa, visa denials, traveling costs to attend higher institutions in the United States, college fees in the United States, cost of living in the United States, lack of available graduate assistantships and lack of awareness about study opportunities. Over $80 \%$ of the respondents agreed to some extent that difficulties in securing study visas, costs of travelling to attend higher institutions, living expenses in the United States were constraints to international students studying in the United States. Nearly all of the respondents stated their agreement that the cost of college fees in the United States was a constraint. About $70 \%$ of the respondents indicated they agreed to some extent that the lack of graduate assistantships and a lack of awareness about study opportunities in the United States are constraints to international students studying in the United States.

The following study abroad support services were rated between low in availability to non-existent by the respondents; USA Financial Aid Advising, United States college recruitments, College Admission Advertisements, and United States Embassy College Fairs. Nearly $60 \%$ of respondents stated that these support services were scarcely available in their home countries. In addition, nearly half of the respondents also stated that student visa advising centers were not readily available in their home countries.

When a statistical test for an association between the level of availability of support services for international students and their motivation for studying at WVU was 
performed, a positive correlation coefficient was found; meaning that the higher the availability of support services for students desiring to study at WVU, the higher the motivations of international students were for choosing to study at WVU.

\section{Conclusions}

The following conclusions are based on the interpretation of the results derived from the data analysis of this study:

A majority of the respondents in this study were males. A majority of the international students who participated in this study were between 26 and 30 years of age. A majority of the respondents were the first in their families to study at West Virginia University. A majority of the respondents were graduate students, most of whom had completed at least a college degree before leaving their home countries.

The most common source of information about studying abroad among international students who participated in this study was the Internet. College recruitment fairs, media advertisements and the United States Embassies were lesser used sources of information by most respondents.

The top motivations of the respondents for studying at WVU were for the following reasons; the United States' reputation for high quality teaching, degrees earned in the United States earn a higher respect at respondents' home countries, the United States provides them a global perspective of their careers, better teaching aids available in the United States, high profile employers in respondents' home countries had a preference for United States- earned degrees, and also due to the fact that WVU offers a broad range of courses of interest to their majors. In addition, many respondents were motivated by WVU's easy admission process, WVU scholarship offers and 
positive recommendations from WVU students. However, many of the international students disagreed that WVU was well advertised in their home countries.

The most significant factors reported to be influential to respondents' choice of WVU were the availability of financial aid at WVU, higher demand for international degrees by employers, positive recommendations from students abroad, the prevalence of advanced research techniques at WVU, as well as, the high demand for international degrees by employers as a factor influencing their choice of WVU.

A majority of the respondents rated difficulties in securing study visas, costs of travelling to attend higher institutions, living expenses in the United States, the cost of college fees, lack of graduate assistantships and a lack of awareness about study opportunities in the United States as constraints affecting international students' motivation to study in the United States.

Overall, a majority of the respondents in this study indicated that support services for students interested in studying abroad, such as USA Financial Aid Advising, United States college recruitments, College Admission Advertisements, and United States Embassy College Fairs were not widely available in their home countries. Many students also reported that visa advising centers were not readily available in their home countries.

A positive correlation coefficient was found between level of availability of support services for studying in the United States and students' motivation for studying at WVU; meaning that the higher the availability of support services for students desiring to study at WVU, the higher the motivations of international students were for choosing to study at WVU. 


\section{Recommendations}

The following conclusions are based on the interpretation of the results of this study of factors associated with international students' motivation to study at West Virginia University:

1. It is recommended that support services, such as financial aid advising, college recruitment fairs, and visa advising centers should be organized for students outside the United States who aspire to apply to WVU.

2. It is recommended that West Virginia University partners with the United States Consulate across developing countries to organize college recruitment fairs and promote avenues for marketing higher education opportunities that the institution offers to international students.

3. It is recommended that West Virginia University, through its International Students' Office, harness the Internet and international TV media to advertise the diverse study and research opportunities at the University across the globe.

4. It is also recommended that WVU continues to encourage its student, faculty and alumni to promote the institution to prospective students around the world. 


\section{REFERENCES}

Altbach, P. G. (2003). Why the United States will not be a market for foreign higher education products: a case against GATTS. International Higher Education, 30(5), Boston College, MA.

American Association of University Professors. (2004). Foreign Students Decline to Study at U.S. Universities. American Association of University Professors Academia [Online] 90(4). Retrieved on February17'2009, from http://www.aaup.org/AAUP/pubsres/academe/2004/JA/NB/ForStuDecl.htm

American Council on Education (2006). Monday buzz: new report documents reversal in international student enrollment declines, continued growth in number of U.S. students studying abroad. News Room Brief Retrieved on February 17, 2009, from http://www.acenet.edu/AM/Template.cfm?Section=News_Room\&TEMPLATE=/ CM/ContentDisplay.cfm\&CONTENTID $=18903$

Ary, D., Jacobs, L. C., Razavieh, A., \& Sorenson, C. (2006). Introduction to research in education ( $7^{\text {th }}$ ed.) Belmont, CA: Thomson Wadsworth.

Blaug, M. \& Woodhall, M. (1981). 'Survey of overseas students in British higher education 1980,' in P. Williams (ed.) The overseas student question: studies for a policy, pub. Heinemann, London.

Bureau of Industry Economics. (1989), Exporting Australia's tertiary education services, Information Bulletin 16, AGPS, Canberra.

Chandler, A. (1989). Obligation or Opportunity, IIE Report No 18, IIE, New York. 
Dillman, D.A. (2000). Mail and Internet surveys: the tailored design method ( $2^{\text {nd }}$ ed.) John Wiley: New Jersey.

Grant, F. S. (2003). Getting back on track: Saudi study in the United States. SaudiAmerican Forum Essay Series (17), July 16, 2003.

Hatakenaka, S. (2004). Internationalism in higher education: a review. An executive summary of the Higher Education Policy Institute, United Kingdom, 2004. Accessed on January 7, 2009 from www.hepi.ac.uk/downloads/12InternationalismReportExecutiveSummary.doc

Hill, C., Romm, T. \& Patterson, P. (1992). The pre-purchase decision making process experienced by overseas students in Australia: a longitudinal, retrospective study, ANZAM, University of Western Sydney, Sydney.

IDP Education (1994). Comparative analysis of costs of postgraduate courses for overseas students in Australia, New Zealand, the UK, Canada and the US, AGPS, Canberra.

Institute of International Education (2005). Statistics on International Student Mobility 2005 in Open Doors Report, 2005, Institute of International Education, Washington DC

Institute of International Education (2008). Open Doors 2008: International Students in the United States, National Press Club Briefing - November 17, 2008, Washington DC.

Kiviniemi, M. T. \& Bevins, R.A. (2007) Affect-Behavior Associations in Motivated Behavioral Choice: Potential Transdisciplinary Links In: Issues in the Psychology of Motivation, Zelick P.R. (ed.), Nova Science Publishers, p65. 
Knight, J., de Wit, H. (1997). Internationalization of higher education in Asia Pacific Countries. European Association for International Education, Amsterdam.

Krejcie, R. V., \& Morgan, D. W. (1970). Determining sample size for research activities. Journal of Educational and Psychological Measurement, 30, pp. 607-610.

Lawley, M.A. (1993). Factors influencing the choice of destination in international education: the case of Hong Kong. An unpublished Masters in Business thesis, University of Southern Queensland, Australia.

Mazzarol, T. \& Geoffrey N. S. (2002). Push-pull factors influencing international student destination choice. International Journal of Educational Management, 16(2), 2002.

NASFA, (2008). The Economic Benefits of International Education to the United States: A Statistical Analysis, 2007-2008. National Association of Foreign Student Advisers, Washington, DC. Accessed on February 18, 2009 from http://www.nafsa.org/public_policy.sec/international_education_1/eis_2008

Noel-Levitz, (2007). Why did they enroll: the factors influencing college choice? National Research Report, 2007. Accessed on January 8, 2009 from www.noellevitz.com/factors

Rao, G.L. (1979). Brain drain and foreign students - a study of the attitudes and intentions of foreign students in Australia, the USA, Canada and France. University of Queensland Press, Brisbane, Australia.

Robinson, J.P., Shaver, P.R., \& Wrightsman, L.S. (1991). Criteria for scale selection and evaluation. In J.P. Robinson, P.R. Shaver \& L.S. Wrightsman (Eds.) Measures of 
personality and social psychological attitudes (pp. 1-16) New York: Academic Press.

Schnitzer, K. \& Zempel-Gino, M. (2002). Euro student: social and economic conditions of student life in Europe. Hochscul Information Systems, Hannover.

Shenoy, A. (2002). International students: the global commerce of higher education. Encyclopedia of Education by the Gale Group, Inc. Accessed on $17^{\text {th }}$ February, 2009 from http://education.state university.com/pages/2129/InternationalStudents.html

Slagle, E. (2006). West Virginia University works to attract foreign students. The Dominion Post Newspaper Editorial, 23, January, 2006.

Soo, K. T. \& Elliott, C. (2008). Price doesn’t matter: overseas students in UK higher education. Seminar Paper presented at the 2008 Scottish Economic Society Annual Conference, Lancaster University, UK.

Steadman, G.T. \& Dagwell, R.H. (1990). Survey of overseas students in Queensland. Australian Universities Review, 1 \& 2, pp. 59-63, University of Queensland, Australia.

UNESCO (2006). Comparing education statistics across the world. Global Education Digest, UNESCO Institute for Statistics, Montreal 2006.

Verbik L. (2007). International Student Mobility: Patterns and Trends. World Education News and Reviews 20(10), October 2007. Accessed on January 8, 2009 from http://www.wes.org /ewenr/ 07oct/feature.htm 
WVU (2008). A guide for international students. West Virginia University,

Morgantown, WV. Accessed on January 8, 2009 from

http://www.arc.wvu.edu/admissions/intl_brochure3.html 
APPENDICES 
APPENDIX A

First Cover Letter 
Dear WVU Student,

On Monday, April 27, you received an e-mail message from the international students' office, asking you to participate in a research study examining factors associated with international students' motivations to study abroad and particularly here at West Virginia University. If you have filled out the survey, thank you very much! If not, PLEASE, take a few minutes to go to the link below and fill out the online survey. http://simpleforms.scripts.wvu.edu/sf/InternationalStudents@,WVU/

A vibrant international student population translates into a diverse and a multicultural environment for institutions of higher education. However, securing and maintaining international student enrollments requires an understanding of international students' motivations for studying abroad. As an international student taking classes here at West Virginia University, you are a valuable source for helping us to understand factors associated with international students' motivations to study abroad and particularly here at West Virginia University.

I am Abimbola Akintounde and I am a graduate student in Agricultural Extension and Education at West Virginia University. Under the supervision of my advisor, Dr. Deborah A. Boone, I am conducting a research study to determine factors that influence international students to study abroad and particularly here at West Virginia University. The results of this study will be used to prepare a thesis to partially fulfill the requirements for a Masters of Science degree in Agriculture and Extension Education at West Virginia University. West Virginia University's IRB acknowledgement of this research is on file.

You must be 18 years of age or older to participate in this survey. Your participation in this research is completely voluntary. You may stop filling out this survey at any time or skip any questions that you do not wish to answer. However, your completion of this survey is vital to the success of this study. The survey should only take about 15 minutes and your response will be held as confidential as possible. There are no penalties to your class standing if you choose not to participate. Please complete the survey online by visiting the link below: http://simpleforms.scripts.wvu.edu/sf/InternationalStudents@,WVU/ before May 6, 2009.

You may contact Dr. Boone at Debby.Boone@mail.wvu.edu or by phone at 304-2934832 x 4482 if you have any questions. Abimbola can be reached at aakintou@mix.wvu.edu. Thank you, we appreciate your time and effort.

Sincerely,

Abimbola Akintounde

Graduate Student
Deborah A. Boone, Ph.D.

Assistant Professor 
APPENDIX B

Second Cover Letter 
Dear WVU Student,

To everyone who responded to an e-survey from the international students' office on Monday, April 27, Friday, May 8, Thursday, May 14 or Monday, May 18, thank you for your thoughtful responses. Your tremendous contributions to the survey are inestimable.

If you are yet to complete the survey, PLEASE, take a few minutes to go to the link below and fill out the online survey. http://simpleforms.scripts.wvu.edu/sf/InternationalStudents@,WVU/

A vibrant international student population translates into a diverse and a multicultural environment for institutions of higher education. However, securing and maintaining international student enrollments requires an understanding of international students' motivations for studying abroad. As an international student taking classes here at West Virginia University, you are a valuable source for helping us to understand factors associated with international students' motivations to study abroad and particularly here at West Virginia University.

I am Abimbola Akintounde and I am a graduate student in Agricultural Extension and Education at West Virginia University. Under the supervision of my advisor, Dr. Deborah A. Boone, I am conducting a research study to determine factors that influence international students to study abroad and particularly here at West Virginia University. The results of this study will be used to prepare a thesis to partially fulfill the requirements for a Masters of Science degree in Agriculture and Extension Education at West Virginia University. West Virginia University's IRB acknowledgement of this research is on file.

You must be 18 years of age or older to participate in this survey. Your participation in this research is completely voluntary. You may stop filling out this survey at any time or skip any questions that you do not wish to answer. However, your completion of this survey is vital to the success of this study. The survey should only take about 15 minutes and your response will be held as confidential as possible. There are no penalties to your class standing if you choose not to participate. Please complete the survey online by visiting the link below: http://simpleforms.scripts.wvu.edu/sf/InternationalStudents@WVU/ before May 6, 2009.

You may contact Dr. Boone at Debby.Boone@mail.wvu.edu or by phone at 304-2934832 x 4482 if you have any questions. Abimbola can be reached at aakintou@mix.wvu.edu. Thank you, we appreciate your time and effort.

Sincerely,

Abimbola Akintounde

Graduate Student
Deborah A. Boone, Ph.D.

Assistant Professor 
APPENDIX C

Questionnaire 


\section{Factors that Influence International Students' Motivations to Study at West Virginia University}

\begin{tabular}{|c|c|c|c|c|c|c|c|}
\hline \multicolumn{8}{|l|}{$\begin{array}{l}\text { Instructions: Use the following } \\
\text { CLICK on the rating that best } \\
\text { SD - Strongly Disagree } \\
\text { D - Disagree } \\
\text { DS - Disagree Slightly } \\
\text { AS - Agree Slightly } \\
\text { A - Agree } \\
\text { SA - Strongly Agree } \\
\text { NA - Does not apply to me. }\end{array}$} \\
\hline $\begin{array}{l}\text { I chose to study in the United States } \\
\text { for its reputation for high quality } \\
\text { teaching. }\end{array}$ & SD & D & DS & $\begin{array}{c}\text { AS } \\
0\end{array}$ & $\begin{array}{l}\mathrm{A} \\
\mathrm{O}\end{array}$ & SA & $\begin{array}{c}\text { NA } \\
\mathrm{O}\end{array}$ \\
\hline $\begin{array}{l}\text { The United States offers better } \\
\text { teaching aids than I could have } \\
\text { found in my home country. }\end{array}$ & $\mathrm{SD}$ & $\mathrm{D}$ & DS & $\stackrel{\text { AS }}{\bigcirc}$ & $\stackrel{A}{\bigcirc}$ & $\begin{array}{c}\text { SA } \\
\mathrm{O}\end{array}$ & $\stackrel{N A}{O}$ \\
\hline $\begin{array}{l}\text { I chose WVU because the school } \\
\text { offered me a scholarship to pursue } \\
\text { my degree. }\end{array}$ & $\stackrel{\text { SD }}{\bigcirc}$ & $\stackrel{D}{O}$ & DS & $\stackrel{\text { AS }}{\bigcirc}$ & $\mathrm{A}$ & SA & $\stackrel{N A}{\bigcirc}$ \\
\hline $\begin{array}{l}\text { I chose to study at WVU because the } \\
\text { admission process was easy for me. }\end{array}$ & $\begin{array}{c}\mathrm{SD} \\
\mathrm{O}\end{array}$ & $\mathrm{D}$ & DS & AS & $\stackrel{A}{O}$ & $\mathrm{SA}$ & $\stackrel{N A}{O}$ \\
\hline $\begin{array}{l}\text { The positive level of multicultural } \\
\text { diversity was a factor in me } \\
\text { choosing to study at WVU. }\end{array}$ & $\stackrel{S D}{\bigcirc}$ & $\mathrm{D}$ & DS & AS & $\stackrel{A}{\bigcirc}$ & SA & $\stackrel{N A}{O}$ \\
\hline $\begin{array}{l}\text { I chose to attend WVU in order to be } \\
\text { closer to my family members here. }\end{array}$ & $\stackrel{S D}{O}$ & $\mathrm{D}$ & DS & $\begin{array}{c}\text { AS } \\
0\end{array}$ & A & SA & \\
\hline $\begin{array}{l}\text { WVU is well advertised in my home } \\
\text { country. }\end{array}$ & SD & $\mathrm{D}$ & DS & AS & A & $\begin{array}{c}S A \\
O\end{array}$ & \\
\hline $\begin{array}{l}\text { WVU offers a broad range of courses } \\
\text { of interest to my major. }\end{array}$ & $\begin{array}{c}S D \\
0\end{array}$ & D & DS & $\begin{array}{c}\text { AS } \\
0\end{array}$ & $\stackrel{A}{O}$ & $\begin{array}{c}S A \\
O\end{array}$ & $\begin{array}{c}\text { NA } \\
\text { O }\end{array}$ \\
\hline $\begin{array}{l}\text { Graduates with degrees earned in } \\
\text { the United States are highly } \\
\text { respected in my home country. }\end{array}$ & $\stackrel{S D}{\bigcirc}$ & D & DS & AS & A & SA & \\
\hline $\begin{array}{l}\text { Studying in the United States } \\
\text { provides me a global perspective of } \\
\text { my career. }\end{array}$ & $\mathrm{SD}$ & D & DS & $\begin{array}{c}\text { AS } \\
0\end{array}$ & A & $\begin{array}{c}\text { SA } \\
\mathrm{O}\end{array}$ & NA \\
\hline
\end{tabular}


SimpleForms :: Factors that Influence International Students' Motivations to Study at Wes... Page 2 of 8

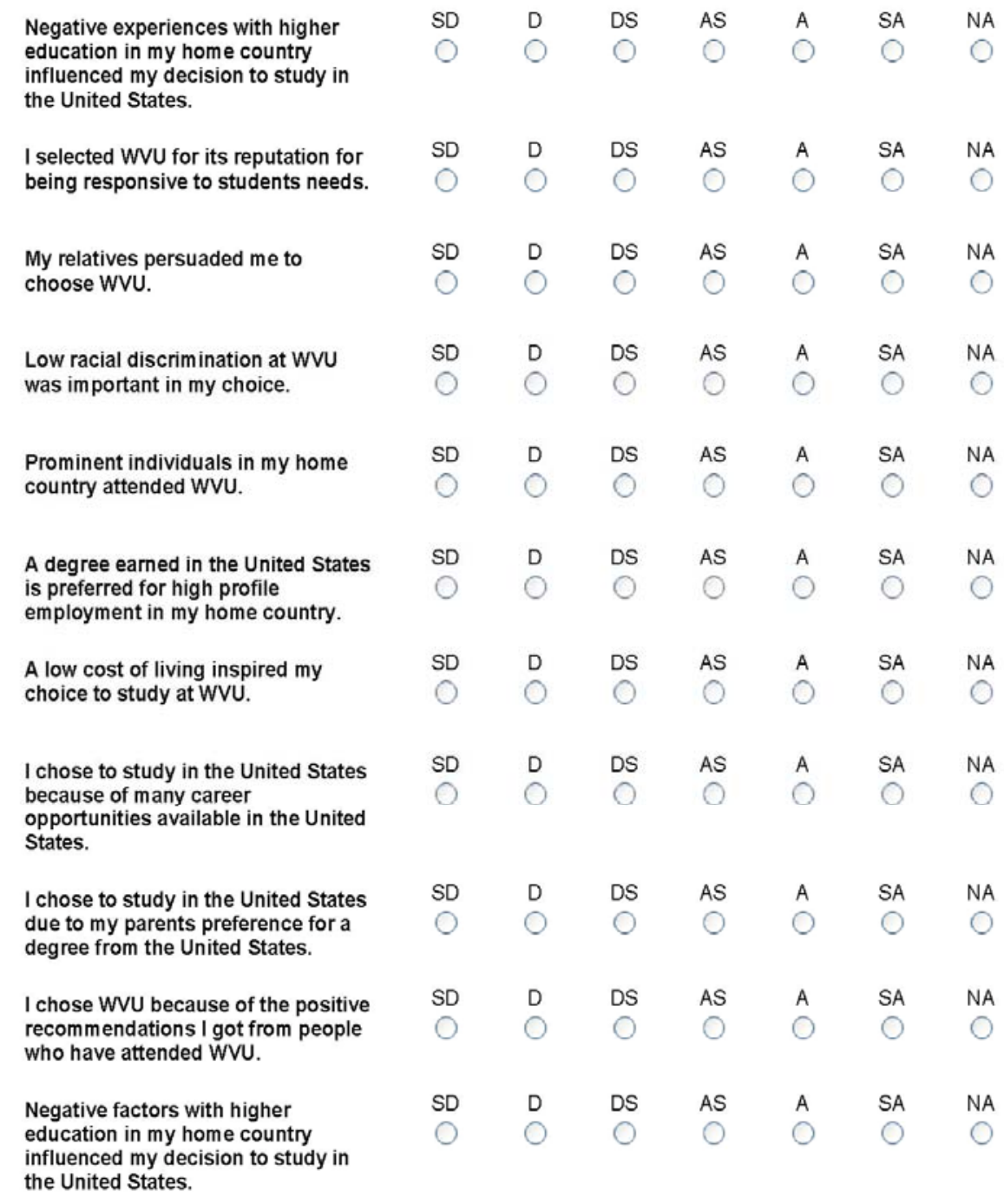

Section II. Factors influencing the decision to study at WVU.

Instructions: Use the following six point scale to rate factors that influenced your decision to study at West Virginia University. CLICK on the rating that best corresponds to your level of agreement as it relates to your decision to study at West Virginia University.

SD - Strongly Disagree

D - Disagree

DS - Disagree Slightly

AS - Agree Slightly

A - Agree

SA - Strongly Agree

NA - Does not apply to me.

$\begin{array}{llllllll}\text { Uncertainty of the length of study at } & \text { SD } & D & \text { DS } & \text { AS } & \text { A } & \text { SA } & \text { NA } \\ \text { institutions in my home country. } & O & O & O & O & O & 0 & 0\end{array}$


SimpleForms :: Factors that Influence International Students' Motivations to Study at Wes... Page 3 of 8

\begin{tabular}{|c|c|c|c|c|c|c|}
\hline $\begin{array}{l}\text { Difficulties with gaining admission } \\
\text { into universities in my home } \\
\text { country. }\end{array}$ & $\begin{array}{c}S D \\
0\end{array}$ & D & $\begin{array}{l}\text { DS } \\
0\end{array}$ & $\begin{array}{c}\text { AS } \\
0\end{array}$ & $\mathrm{O}^{A}$ & $\begin{array}{l}S A \\
0\end{array}$ \\
\hline $\begin{array}{l}\text { Unemployment rates for graduates } \\
\text { in my home country. }\end{array}$ & $\begin{array}{c}S D \\
0\end{array}$ & D & $\begin{array}{l}\text { DS } \\
0\end{array}$ & $\begin{array}{c}\text { AS } \\
0\end{array}$ & A & $\begin{array}{l}\text { SA } \\
\mathrm{O}\end{array}$ \\
\hline Availability of financial aid at WVU. & $\begin{array}{c}S D \\
0\end{array}$ & D & DS & AS & $\mathrm{A}^{\mathrm{A}}$ & SA \\
\hline High quality of teaching at WVU. & $\begin{array}{c}S D \\
0\end{array}$ & D & $\begin{array}{l}\text { DS } \\
0\end{array}$ & $\begin{array}{c}\text { AS } \\
0\end{array}$ & A & SA \\
\hline $\begin{array}{l}\text { Higher demand for international } \\
\text { degrees by employers in my home } \\
\text { country. }\end{array}$ & $\begin{array}{c}S D \\
0\end{array}$ & D & $\begin{array}{c}\text { DS } \\
0\end{array}$ & $\begin{array}{c}\text { AS } \\
0\end{array}$ & $\stackrel{A}{O}$ & $\begin{array}{c}S A \\
0\end{array}$ \\
\hline $\begin{array}{l}\text { Language similarities with my home } \\
\text { country. }\end{array}$ & $\begin{array}{l}S D \\
0\end{array}$ & $\begin{array}{l}D \\
O\end{array}$ & $\begin{array}{l}\text { DS } \\
0\end{array}$ & $\begin{array}{c}\text { AS } \\
0\end{array}$ & A & $\begin{array}{l}\text { SA } \\
\mathrm{O}\end{array}$ \\
\hline $\begin{array}{l}\text { Positive recommendations received } \\
\text { from students studying outside my } \\
\text { home country. }\end{array}$ & $\begin{array}{c}\text { SD } \\
0\end{array}$ & D & $\begin{array}{c}\text { DS } \\
0\end{array}$ & $\begin{array}{c}\text { AS } \\
0\end{array}$ & $\mathrm{~A}$ & SA \\
\hline $\begin{array}{l}\text { Student recruitment programs } \\
\text { organized by United States } \\
\text { institutions in my home country. }\end{array}$ & $\begin{array}{c}\text { SD } \\
0\end{array}$ & $0^{0}$ & $\begin{array}{c}\text { DS } \\
0\end{array}$ & $\begin{array}{c}\text { AS } \\
0\end{array}$ & $\stackrel{A}{O}$ & $\begin{array}{l}\text { SA } \\
0\end{array}$ \\
\hline $\begin{array}{l}\text { Presence of relatives in the United } \\
\text { States. }\end{array}$ & $\begin{array}{c}S D \\
0\end{array}$ & D & $\begin{array}{c}\text { DS } \\
0\end{array}$ & $\begin{array}{c}\text { AS } \\
0\end{array}$ & $\begin{array}{l}A \\
0\end{array}$ & $\begin{array}{c}S A \\
0\end{array}$ \\
\hline $\begin{array}{l}\text { Prevalence of advanced research } \\
\text { techniques at WVU. }\end{array}$ & $\begin{array}{c}\text { SD } \\
0\end{array}$ & $0^{0}$ & $\begin{array}{c}\text { DS } \\
0\end{array}$ & AS & A & SA \\
\hline Others: & $\begin{aligned} \text { SD } \\
0\end{aligned}$ & D & $\begin{array}{l}\text { DS } \\
0\end{array}$ & AS & $\begin{array}{l}A \\
0\end{array}$ & $\begin{array}{c}\text { SA } \\
\text { O }\end{array}$ \\
\hline
\end{tabular}
If you selected "other", please
specify

Section III. Constraints to study migration decision.

Instructions: Use the following six point scale to rate perceived constraints that could affect international students decision to study at West Virginia University. CLICK on the rating that best corresponds to your level of agreement with each statement.

http://simpleforms.scripts.wvu.edu/sf/InternationalStudents@WVU/

$5 / 26 / 2009$ 
SimpleForms :: Factors that Influence International Students' Motivations to Study at Wes... Page 4 of 8

\begin{tabular}{|c|c|c|c|c|c|c|c|}
\hline $\begin{array}{l}\text { SD - Strongly Disagree } \\
\text { D - Disagree } \\
\text { DS - Disagree Slightly } \\
\text { AS - Agree Slightly } \\
\text { A - Agree } \\
\text { SA - Strongly Agree } \\
\text { NA - Does not apply to me. }\end{array}$ & & & & & & & \\
\hline Constraints that affect international students & sions & dy in & Jnitec & tes. & & & \\
\hline Difficulties in securing visa. & $\begin{array}{c}S D \\
0\end{array}$ & $\begin{array}{l}D \\
0\end{array}$ & $\begin{array}{l}\text { DS } \\
0\end{array}$ & $\begin{array}{c}\text { AS } \\
0\end{array}$ & $\begin{array}{l}A \\
0\end{array}$ & $\begin{array}{l}\text { SA } \\
0\end{array}$ & $\begin{array}{c}\text { NA } \\
0\end{array}$ \\
\hline Visa denials. & $\begin{array}{c}S D \\
0\end{array}$ & D & $\begin{array}{c}\text { DS } \\
0\end{array}$ & AS & $\stackrel{A}{O}$ & $\begin{array}{c}\text { SA } \\
0\end{array}$ & NA \\
\hline $\begin{array}{l}\text { Costs of traveling to attend an } \\
\text { institution of higher learning in the } \\
\text { United States. }\end{array}$ & $\begin{array}{l}S D \\
0\end{array}$ & D & $\begin{array}{l}\text { DS } \\
0\end{array}$ & $\begin{array}{c}\text { AS } \\
0\end{array}$ & $\stackrel{A}{O}$ & $\begin{array}{l}\text { SA } \\
0\end{array}$ & $\begin{array}{c}\text { NA } \\
\mathrm{O}\end{array}$ \\
\hline $\begin{array}{l}\text { Cost of college fees in the United } \\
\text { States. }\end{array}$ & $\begin{array}{c}S D \\
0\end{array}$ & D & $\begin{array}{c}\text { DS } \\
0\end{array}$ & $\begin{array}{c}\text { AS } \\
0\end{array}$ & $\mathrm{O}^{\mathrm{A}}$ & $\begin{array}{c}S A \\
0\end{array}$ & $\begin{array}{c}\text { NA } \\
0\end{array}$ \\
\hline Cost of living in the United States. & $\begin{array}{c}S D \\
0\end{array}$ & D & $\begin{array}{c}\text { DS } \\
0\end{array}$ & $\begin{array}{c}\text { AS } \\
0\end{array}$ & $\begin{array}{l}A \\
O\end{array}$ & $\begin{array}{l}S A \\
0\end{array}$ & $\begin{array}{c}\text { NA } \\
0\end{array}$ \\
\hline $\begin{array}{l}\text { Lack of available graduate } \\
\text { assistantships. }\end{array}$ & $\begin{array}{l}S D \\
0\end{array}$ & D & $\begin{array}{c}\text { DS } \\
0\end{array}$ & $\begin{array}{c}\text { AS } \\
0\end{array}$ & $\begin{array}{l}A \\
O\end{array}$ & $\begin{array}{l}\text { SA } \\
0\end{array}$ & $\begin{array}{c}\text { NA } \\
\bigcirc\end{array}$ \\
\hline $\begin{array}{l}\text { Lack of awareness about study } \\
\text { opportunities. }\end{array}$ & $\begin{array}{c}S D \\
0\end{array}$ & D & $\begin{array}{c}\text { DS } \\
0\end{array}$ & $\begin{array}{c}\text { AS } \\
0\end{array}$ & $\begin{array}{l}A \\
O\end{array}$ & $\begin{array}{c}\text { SA } \\
0\end{array}$ & $\begin{array}{c}\text { NA } \\
0\end{array}$ \\
\hline $\begin{array}{l}\text { Perceptions about the United States } \\
\text { in home country. }\end{array}$ & $\begin{array}{c}S D \\
0\end{array}$ & $\begin{array}{l}D \\
0\end{array}$ & $\begin{array}{c}\text { DS } \\
0\end{array}$ & $\begin{array}{c}\text { AS } \\
0\end{array}$ & $\begin{array}{l}A \\
0\end{array}$ & SA & $\begin{array}{c}\text { NA } \\
0\end{array}$ \\
\hline $\begin{array}{l}\text { Perceived religious restrictions in } \\
\text { the United States. }\end{array}$ & $\begin{array}{c}S D \\
0\end{array}$ & $0^{D}$ & $\begin{array}{c}\text { DS } \\
0\end{array}$ & AS & A & SA & NA \\
\hline Transcript evaluation delays. & SD & $D$ & DS & AS & A & SA & NA \\
\hline No testing centers in home country. & SD & D & DS & AS & A & SA & NA \\
\hline $\begin{array}{l}\text { Delays in accessing educational } \\
\text { transcripts. }\end{array}$ & SD & D & DS & AS & A & SA & NA \\
\hline Language barriers. & SD & $D$ & DS & AS & A & SA & NA \\
\hline Fear of adjusting to unfamiliar & SD & D & DS & AS & A & SA & NA \\
\hline
\end{tabular}


SimpleForms :: Factors that Influence International Students' Motivations to Study at Wes... Page 5 of 8

\begin{tabular}{|c|c|c|c|c|c|c|}
\hline weather. & 0 & 0 & 0 & 0 & 0 & 0 \\
\hline $\begin{array}{l}\text { Absence of relatives in the United } \\
\text { States. }\end{array}$ & $\begin{array}{c}\mathrm{SD} \\
\mathrm{O}\end{array}$ & D & $\begin{array}{c}\text { DS } \\
0\end{array}$ & $\begin{array}{c}\text { AS } \\
0\end{array}$ & $\stackrel{A}{O}$ & SA \\
\hline Food and dietary differences. & $\begin{array}{c}\text { SD } \\
0\end{array}$ & $\stackrel{0}{0}$ & $\begin{array}{l}\text { DS } \\
0\end{array}$ & $\begin{array}{c}\text { AS } \\
0\end{array}$ & $\stackrel{A}{0}$ & SA \\
\hline Others: & $\begin{array}{c}\text { SD } \\
0\end{array}$ & $D^{D}$ & $\begin{array}{c}\text { DS } \\
0\end{array}$ & $\begin{array}{c}\text { AS } \\
0\end{array}$ & A & SA \\
\hline
\end{tabular}

If you selected "other", please specify

Section IV. Level of availability of support services.
$\begin{aligned} & \text { Please read each item completely and then CLICK the rating that best indicates their level of existence } \\ & \text { country from } \mathrm{H}=\text { Highly available, } \mathrm{M}=\text { Moderately available, } \mathrm{L}=\text { Low Availability, or } \mathrm{N}=\text { Not available }\end{aligned}$
Rate study support services available in your home country. (Rate accordingly).
$\begin{aligned} & \text { H-Highly } \\ & \text { available } \\ & \text { N- Not available Moderately } \\ & \text { available }\end{aligned}$
USA College Test preparation.
USA Financiability
Student Visa Advising Centers.
International English Programs for
applicants to United States colleges.
United States college recruitments.
College Admission Advertisements.

http://simpleforms.scripts.wvu.edu/sf/InternationalStudents@WVU/ 
SimpleForms :: Factors that Influence International Students' Motivations to Study at Wes... Page 6 of 8

United States Embassy College

Fairs.

Others:

If you selected "other", please specify

Section V. Respondents demographic characteristics

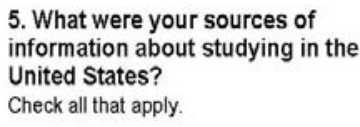

6. Which of your family members earned a degree outside of your home country?

Check all that apply

Thich of your family members

States?

Check all that apply

. Which of your family members earned a degree at West Virginia University?

Check all that apply.

http://simpleforms.scripts.wvu.edu/sf/InternationalStudents@WVU/
College Recruitment Fairs

Media Advertisements

Recommendations from relatives abroad

$\square$ Internet

$\square$ Schools in home country

United States Embassy

$\square$ Visits abroad prior to college

Other

If 'Other' please specify:

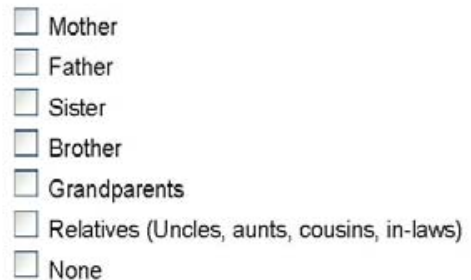

$\square$ Mother

$\square$ Father

$\square$ Sister

$\square$ Brother

$\square$ Grandparents

$\square$ Relatives (Uncles, aunts, cousins, in-laws)

None

$\square$ Mother

Father

Sister

Brother

Grandparents 
SimpleForms :: Factors that Influence International Students' Motivations to Study at Wes... Page 7 of 8

\begin{tabular}{|c|c|}
\hline & $\begin{array}{l}\square \text { Relatives (Uncles, aunts, cousins, in-laws) } \\
\square \text { None }\end{array}$ \\
\hline $\begin{array}{l}\text { 9. What is your fathers highest level } \\
\text { of education? }\end{array}$ & $\begin{array}{l}\square \text { Doctorate } \\
\square \text { Masters/Graduate Certificate } \\
\square \text { Bachelors } \\
\square \text { High School } \\
\square \text { Vocational Studies } \\
\square \text { Elementary School } \\
\square \text { No Formal Schooling }\end{array}$ \\
\hline $\begin{array}{l}\text { 10. What is your mothers highest } \\
\text { level of education? }\end{array}$ & $\begin{array}{l}\square \text { Doctorate } \\
\square \text { Masters/Graduate Certificate } \\
\square \text { Bachelors } \\
\square \text { High School } \\
\square \text { Vocational Studies } \\
\square \text { Elementary School } \\
\square \text { No Formal Schooling }\end{array}$ \\
\hline $\begin{array}{l}\text { 11. Had you travelled internationally } \\
\text { prior to attending WVU? }\end{array}$ & $\begin{array}{l}\square \text { Yes } \\
\square \text { No }\end{array}$ \\
\hline $\begin{array}{l}\text { 12. Are you the first family mem ber } \\
\text { to study outside your home } \\
\text { country? }\end{array}$ & $\begin{array}{l}\square \text { Yes } \\
\square \text { No }\end{array}$ \\
\hline $\begin{array}{l}\text { 13. Are you the first family member } \\
\text { to study at WVU? }\end{array}$ & $\begin{array}{l}\square \text { Yes } \\
\square \text { No }\end{array}$ \\
\hline $\begin{array}{l}\text { 14. How long have you been } \\
\text { studying in the United States? } \\
\text { Please give your response in Months. }\end{array}$ & \\
\hline $\begin{array}{l}\text { 15. How long have you been } \\
\text { studying at WVU? } \\
\text { Please, give your response in Months. }\end{array}$ & \\
\hline $\begin{array}{l}\text { 16. What is your current academic } \\
\text { status at WVU? }\end{array}$ & $\begin{array}{l}\square \text { Freshman } \\
\square \text { Junior } \\
\square \text { Sophomore } \\
\square \text { Senior } \\
\square \text { Masters } \\
\square \text { Doctorate } \\
\square \text { Post Doctorate }\end{array}$ \\
\hline $\begin{array}{l}\text { 17. What college are you enrolled in } \\
\text { at WVU? }\end{array}$ & $\cdots$ \\
\hline 18. What is your major at WVU? & \\
\hline $\begin{array}{l}\text { 19. Are you on a graduate } \\
\text { assistantship here at WVU? }\end{array}$ & $\begin{array}{l}\square \text { Yes } \\
\square \text { No }\end{array}$ \\
\hline
\end{tabular}


SimpleForms :: Factors that Influence International Students' Motivations to Study at Wes... Page 8 of 8

20. What is the highest education level you attained in your home country?

21. What is your age category?

22. Are you a male or a female? 23. Please
origin?

Comments

23. Please name your country of

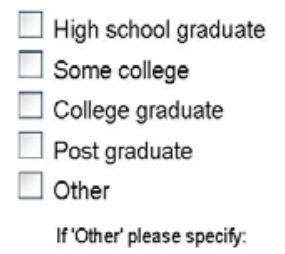

$\square$ 18-21 years

$\square$ 22-25 years

$\square$ 26-30 years

$\square$ 31-35 years

$\square$ 36-40 years

$\square$ Over 40 years

\section{$\square$ Male}

$\square$ Female

-

Submit This Form 
APPENDIX D

Full List of Respondents' Countries of Origin 
Table 15

Full List of Respondents' Countries of Origin

\begin{tabular}{|c|c|c|}
\hline Countries of origin & $N$ & $\%$ \\
\hline India & 77 & 26.0 \\
\hline China & 43 & 14.5 \\
\hline Colombia & 13 & 4.4 \\
\hline Nigeria & 11 & 3.7 \\
\hline Saudi Arabia & 8 & 2.7 \\
\hline Turkey & 8 & 2.7 \\
\hline Germany & 7 & 2.4 \\
\hline Iran & 7 & 2.4 \\
\hline Nepal & 7 & 2.4 \\
\hline Ghana & 6 & 2.0 \\
\hline Kenya & 6 & 2.0 \\
\hline Eritrea & 5 & 1.7 \\
\hline Korea South & 5 & 1.7 \\
\hline Brazil & 4 & 1.4 \\
\hline Kuwait & 4 & 1.4 \\
\hline Mexico & 4 & 1.4 \\
\hline Philippines & 4 & 1.4 \\
\hline Spain & 4 & 1.4 \\
\hline Taiwan & 4 & 1.4 \\
\hline
\end{tabular}


Table 15 (continued)

Full List of Respondents' Countries of Origin

\begin{tabular}{lll}
\hline Countries of origin & $N$ & $\%$ \\
\hline Canada & 3 & 1.0 \\
Ethiopia & 3 & 1.0 \\
Finland & 3 & 1.0 \\
France & 3 & 1.0 \\
Indonesia & 3 & 1.0 \\
Japan & 3 & 1.0 \\
Jordan & 3 & 1.0 \\
Peru & 3 & 1.0 \\
Zambia & 3 & 1.0 \\
Zimbabwe & 3 & 1.0 \\
Argentina & 2 & .7 \\
Burkina Faso & 2 & .7 \\
Cameroon & 2 & .7 \\
Malaysia & 2 & .7 \\
Romania & 2 & .7 \\
South Africa & 2 & .7 \\
Venezuela & 2 & 7 \\
Albania & 2 & \\
\hline & 2 & .7 \\
\hline
\end{tabular}


Table 15 (continued)

Full List of Respondents' Countries of Origin

\begin{tabular}{|c|c|c|}
\hline Countries of origin & $N$ & $\%$ \\
\hline Australia & 1 & .3 \\
\hline Austria & 1 & .3 \\
\hline Bangladesh & 1 & .3 \\
\hline Benin & 1 & .3 \\
\hline Bolivia & 1 & .3 \\
\hline Czech Republic & 1 & .3 \\
\hline Dominica & 1 & .3 \\
\hline Egypt & 1 & .3 \\
\hline Greece & 1 & .3 \\
\hline Guyana & 1 & .3 \\
\hline Hungary & 1 & .3 \\
\hline Italy & 1 & .3 \\
\hline Libya & 1 & .3 \\
\hline New Zealand & 1 & .3 \\
\hline Pakistan & 1 & .3 \\
\hline Poland & 1 & .3 \\
\hline Sweden & 1 & .3 \\
\hline Switzerland & 1 & .3 \\
\hline
\end{tabular}


Table 15 (continued)

Full List of Respondents' Countries of Origin

\begin{tabular}{lcc}
\hline Countries & $N$ & $\%$ \\
\hline Thailand & 1 & .3 \\
Trinidad and Tobago & 1 & .3 \\
United Kingdom & 1 & .3 \\
United States & 1 & .3 \\
Vietnam & 1 & .3 \\
Armenia & 1 & .3 \\
\hline
\end{tabular}


APPENDIX E

Other Factors that Influenced International Students' Decision 
Other factors Influencing International Students’ Decisions to Study at WVU

Other factors specified by Respondents as influencing their decisions to study at WVU are listed as follows:

"My school sends me here. I had no choice."

"Exchange/Study abroad programs developed by WVU."

"Low tuition cost, good foreign language program (Japanese), geographic location (proximity to East Coast)"

"I simply chose WVU because I had spent prior attending the university a year in Morgantown as visitor. WVU was the most convenient choice to attend higher education in a town, where I knew my way around and had already developed close ties to the community."

"Good academic programs"

"My primary motivation was actually the combination of proximity (I live in Washington, PA), and a strong program in my field of study, which has been recommended to me by friends in the field. Receiving a paid TA position would have been the final, deciding factor."

"My parents graduated from WVU. They were the main reason for $m$ transfer to WVU from Australia."

"Main Professor's attitude, approach and fame."

"Regarding the Student recruitment program I have a comment. The main reason for choosing WVU among several other possibilities was due to the work of the chairman of my department, who went to several countries recruiting graduate students. This very direct approach was very succesful and opens a non-formal channel with my home university."

"My seniors did their Masters here at WVU."

"The quality of research and funding for doing scientific research in U.S.A is the main reason to enroll at WVU"

"Time required for obtaining my degree."

"Studying abroad was a requirement of my degree program in my home country. I had two choices and I chose WVU because of its proximity to the east coast."

"Comments from present students attending the WVU are also important for other student to make decision to come to WVU."

"WVU has one of the best Mining faculties in the World. [Professor] is the one of the best professor in mining geomechanics in the World. [Professor] is the one of the most famous Professors in the World." 
“...got scholarship from home country government"

"My sister got her Bachelor's degree at WVU and she is working on her Master's degree here too. Therefore, coming to WVU was an opportunity to get my Master's degree while working and studying with my sister."

"I'm on an athletic team"

"I got pre admit, so it was easy for me to come here without applying to any other university."

"My consultancy in my home country" 
APPENDIX F

Other Constraints Listed by International Students 


\section{Other Constraints Limiting International Students from Studying in the United States}

When respondents were asked to specified other constraints they perceive to hinder international students from fulfilling their aspirations to study in the United States, the following were listed:

"Racial Discrimination"

"Cost of living (not educational) is a barrier, but once students are here, they can pay their monthly expenses. I believe the biggest barrier is the proof of financial support, which is required by the institution to issue I-20.I also would suggest another barrier: educational system in general: different attendance policies, evaluations, grading, writing style."

"Cost of living and cost of tuition and fees."

"Out of State fee cost very high, specially at WVU which does not provide in-state fee even after living in the state for more than 2 year; lack of appropriate provision for study loan or subsistence loan to International student; Obtaining a US Visa is very challenging; Very high fee (\$100 Non Refundable) for making application for US visa and also for getting visa (another \$200) after you are entitled to get visa. This is huge amount for ordinary students of developing nations (about one and half-month's salary of a government employed graduate officers' salary)"

"The most significant for me was the knowledge about the existence of assistantships. These are kind of a mystery where and how to look for it. Thanks god my assistantship found me, otherwise I'll probably be in my home country right now."

"I am a Muslim. Before coming to US, everyone in my home country was making me scare that US government is very hard at Muslims, so I should not plan to go to USA. I was extremely scared in the beginning. But with the passage of time I have found that common people are very nice everywhere in USA. I never faced any prejudices and bad behavior"

"Culture Shock Discrimination"

"There are many other countries which are attractive for international students as well. From my experience international students often choose a country closer to their home country or a country with a better reputation, as perceived in their home country." 
APPENDIX G

Other Support Services Listed by International Students 
Other support services listed by the WVU international students who participated in the study include:

"If any support services are available in my home country, they are either very expensive or not in sufficient amount."

"There is a "American Culture center" in my home town where I can learn some stuff of the college process but specific assistantships for graduate studies are found just by Internet..or by Luck."

"Government Scholarships to go to USA"

"Partnerships among particular institutions which support exchanges among themselves."

"I graduated from an American high school..."

"Scholarship from home country government" 
APPENDIX H

Comments from Respondents 


\section{Comments from Survey Participants}

The following statements are quoted comments written by the respondents and do not in any form construe the opinion of this research:

"Like the survey questions. Good luck with the research. Thanks"

"The professors in my department are very supportive and helpful. Of course, they are expertise their professional field. It is very fortunate that I choose study HR\&E, WVU."

"Good Job!"

"I greatly appreciate all aids from WVU, in my eyes, WVU is a wonderful school. Thank you all."

"I would be good if someone gave more assistant to international students about how to use the mix and the master's account, so that the can have access to their information, but also to the computers in the library and the different laboratories. Besides that, you do provide a good service on giving information related to visas and I20."

"My home country is sending about 20 students to the United States and more specifically here to WVU starting from fall of 2009. I believe this is one of the smartest moves the Iraqi government has made because it is in need for educated people with international experience to rebuild this war-torn country. Leaving to the U.S. was my dream since middle school. I managed to get here. Graduated last December with a nice GPA and continuing with my graduate studies at the moment. American degrees are very respected back in the Middle East and their holders are given higher precedence than local universities' graduates. Good luck with you research...."

"WVU is unknown in South Korea. When I search for WVU in the Korean web sites. There is nothing. Actually, there are lots of information about mining. You guys need ADVERTISING to get more kids. My parents don't like me to graduate from WVU because nobody knows WVU in Korea. People though that WVU is in Virginia. They don't know West Virginia. WVU needs strategic approaches for change of the negative image. What I want to recommend is 24 hours LIBRARY! If you guys want kids to successful in the future, make a condition for studying. I couldn't believe that the main library closes at 2:00 a.m. If I knew this, I wouldn't come here. Then do I recommend WVU to my friends? WVU might save some money. Money is more important than students? WVU would NEVER get good kids to enhance WVU's image. I like to say one more thing. I will go to graduate school. But I found a very interesting thing while I am researching for the WVU graduate program (I am not going to say specific department). Some professor only has M.A degree, but they have lectures in the graduate program. I don't think that their lectures are not good. But people who want to go to gradate school will consider professor's work, degree, career etc. Try to get great professors, then WVU gets great kids as well. Money is the matter? Don't Sweat the Small Stuff! I hope my comments will be helpful."

"This Survey is too long! Good luck" 
"I think the biggest barriers to study in US are the language, visas and financial aids. There is very low knowledge of WVU in my country. The visits of the MAE chairman to Colombia have helped a lot for more students coming to WVU. The assistantship is an incredible help for us to study here, without it, a lot of us could not have studied here."

\section{“THANK YOU !!"}

"I would be good if someone gave more assistant to international students about how to use the mix and the master's account, so that the can have access to their information, but also to the computers in the library and the different laboratories. Besides that, you do provide a good service on giving information related to visas and I20."

"I am from Hong Kong."

"Studying in the US is a great experience that teaches international students to live independently away from their families and build a stronger sense of responsibility."

"WVU is a good place to study; only that funding should be made available for graduate studies."

"WVU is a good choice for international students to get a graduate education in the USA. Assistantships are usually available for good students and in some"

"The tuition for international students is very high. Offering at least a 3 credit hour Waiver for all qualified (for example students with high GRE scores) international students would be an incentive for merit students and will improve the quality of educational atmosphere in the University."

"People in Pakistan think that every thing will be ok once you enter USA. I was also expecting to get funding/assistantship immediately. But it could become possible after one complete year. This one year was of great trouble for me. I suggest that international students should be allowed to work off-campus so as to meet their expenditures."

"I like WVU because it's slow pace provides me the guided opportunity to discover a new country at my own pace-I find that how it paces its education is really a factor for me, along with the availability of a vibrant social student scene among others."

"[Department] is the most racist department of WVU."[SIC]

"Like the survey questions. Good luck with the research. Thanks"

"I hope the findings of your study will help the US universities, specially the WVU to develop some international student friendly rules and regulation especially in providing loans, in-state fee after one years' study and so on. GOOD LUCK!!!"”

"I wish the international office could give seminars to professors at WVU to help them understand the difficulties some international students may face and how to deal with them" 
"WVU should increase the staff level and recruiting efforts to increase international student enrollments. Increased scholarships to under-represented countries as well as graduate assistantships would help increase recruitment."

"First of all... your section I and section II sound like the exact same thing to me - how are my 'motivations' supposed to be different from 'factors'? Is this not the exact same thing? There are also some questions that are slightly differently worde 2 but apparently ask the same thing... Also, on the 'constraints' section - it is slightly unclear to me, whether the statement negative or positive.. I THINK you want me to answer: are "visa denials" a constraint? Strongly agree if they are indeed a problem, and disagree if I do not view them as a problem? But I am not $100 \%$ positive, and I fear it may be confusing more of your target audience here. You may want to revise your questionnaire slightly before you use if for your thesis. Best of luck!"

"I greatly appreciate all aids from WVU, in my eyes, WVU is a wonderful school. Thank you all."

"I love it here, however I think the Foreign language department should receive more support, financially and academically."

"I want to mention that there are some sort of discrimination atmosphere against Saudis students because of their religion which is Islam. Particularly in the [college]. I wish if there is an office or a person whom we can report to our discrimination incidents with employees at the university, and I hope this office or person has enough power to get our rights, and be fair enough. Thanks"

"If Assistantships are stopped International students would stop coming to WVU" "If Assistantships are stopped International students would stop coming to WVU" "Good luck with your survey!!"

"I love WVU professors and students are friendly. Racial discrimination is non existent on campus. Bigotry towards other people's culture is minimal. Getting a graduate assistant ship, however is one tough thing international graduate students have to contend with given that most GA positions require people with excellent communication skills in English of course, a thing many international students lack given that their accent is perceived as inability to communicate fluently."

"When people from all over the globe are pursuing higher studies in U.S.A and contributing economically and academically, why not the universities help or fight against the Law that eradicates jobs for International Students???"

"Hope it is easier for Chinese students get visa to study abroad."

"For the graduate level studies, I observe that the biggest influence on studying abroad does not come from family members, but from friends who study abroad. Friends mostly encourage you to apply to overseas programs." 
"I hope WVU would help encourage international students to go back to their countries to serve their people better using the knowledge they gained here because most international students who study here (and in the US in general) do not go back to their home countries where they can contribute more in effecting change. OISS should have a program on that" 
VITA

Abimbola Akintounde

May, 1998

Wesley College of Science, Ibadan, Nigeria

May, 2005

Bachelors of Science

Agricultural Extension and Rural Development

University of Ibadan, Nigeria

October, 2005 to May, 2007

Program Assistant, Human Security in Conflicts and Emergencies Community-Based Project, ActionAid International Nigeria

May, 2008

Masters of Science

Rural Development and Nutrition (Minor: Rural Economics and Management)

Ghent University, Belgium

August, 2009

Masters of Science

Agricultural and Extension Education

West Virginia University, Morgantown

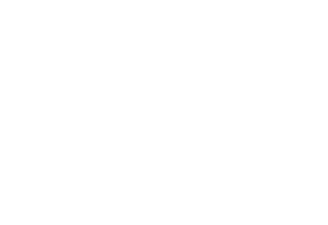

